\title{
Cavity-based secondary mineralization in volcanic tuffs of Yucca Mountain, Nevada: a new type of the polymineral vadose speleothem, or a hydrothermal deposit?
}

\author{
Yuri V. Dublyansky ${ }^{1,2}$ and Sergey Z. Smirnov ${ }^{1}$
}

\begin{abstract}
:
Dublyansky Y. V. and Smirnov S. Z. 2005. Cavity-based secondary mineralization in volcanic tuffs of Yucca Mountain, Nevada: a new type of the polymineral vadose speleothem, or a hydrothermal deposit? International Journal of Speleology, 34 (1-2), 25-44. Bologna (Italy). ISSN 0392-6672.

Secondary minerals (calcite, chalcedony, quartz, opal, fluorite, heulandite, strontianite) residing in open cavities in the Miocene rhyolite tuffs of Yucca Mountain, Nevada have been interpreted by some researchers as "speleothemic" formations, deposited as a result of downward infiltration of meteoric waters (DOE, 2001, Whelan et al., 2002). The major mineral of the paragenesis, calcite, shows spectacular trend of the textural and crystal morphology change: from anhedral granular occurrences, through (optional) platelet, bladed and scepter varieties, to euhedral blocky morphologies. The trend is consistent with the overall decrease in the supesaturation of the mineral forming solution. Stable isotope properties of calcite evolve from ${ }^{13} \mathrm{C}$-enriched $\left(\delta^{13} \mathrm{C}=+4\right.$ to $+9 \%$ o PDB $)$ at early stages of growth to ${ }^{13} \mathrm{C}$-depleted $(-5$ to $-10 \%)$ at late stages. The non-cyclic character of the isotope record and extreme variations of isotopic values argue against the meteoric origin of mineral forming fluids. The $\delta^{13} \mathrm{C}>4 \%$ PDB require isotope partitioning between dissolved $\mathrm{CO}_{2}$ and $\mathrm{CH}_{4}$, which is only possible in reducing anoxic environment, but not in aerated vadose zone.

Fluid inclusions studied in calcite, quartz and fluorite revealed that the minerals were deposited from thermal solutions. The temperatures were higher at early stages of mineral growth $\left(60\right.$ to $\left.85^{\circ} \mathrm{C}\right)$ and declined with time. Most late-stage calcites contain only all-liquid inclusions, suggesting temperatures less than ca. $35-50^{\circ} \mathrm{C}$. Minerals collected close to the major fault show the highest temperatures. Gases trapped in fluid inclusions are dominated by $\mathrm{CO}_{2}$ and $\mathrm{CH}_{4}$; Raman spectrometry results suggest the presence of aromatic/cyclic hydrocarbon gases. The gas chemistry, thus, also indicates reduced (anoxic) character of the mineral forming fluids.

Secondary minerals at Yucca Mountain have likely formed during the short-term invasion(s) of the deep-seated aqueous fluids into the vadose zone. Following the invasion, fluids, initially equilibrated with the deep (reduced, anoxic) environment, evolved toward equilibrium with the new environment (cooling, degassing, mixing with shallow oxidizing waters, etc.). While some features of mineralization are compatible with the "speleothemic" or "meteoric infiltration" model, most of the evidence does not lend itself to rational explanation within this model.
\end{abstract}

Keywords: mineralogy, fluid inclusions, isotopes, thermal fluids, genesis.

Received 15 November 2002; Revised 1 May 2005; Accepted 31 May 2005.

\section{INTRODUCTION}

The subject of this paper is the secondary minerals found in open cavities (lithophysae and fractures) in rhyolitic tuffs of the thick vadose zone of Yucca Mountain, Nevada, USA. Cavities host a suite of secondary calcite and silica minerals, which have been interpreted by some researchers as the product of gravity-driven percolation of meteoric waters through the vadose zone ("meteoric infiltration" model; Paces et al., 2001; Whelan et al., 2002; 2003b; Wilson et al., 2003). An alternative interpretation calls for the

1- Institute of Mineralogy and Petrography, Russian Academy of Sciences, Siberian Branch 630090, Novosibirsk, RUSSIA.

2- Museo Tridentino di Scienze Naturali, via Calepina, 14, I38100 Trento, TN, ITALIA. deposition of these minerals from thermal waters that welled up along the permeable deep-seated fault zone (Dublyansky et al., 2001; 2003; Smirnov \& Dublyansky, 2001). The "hydrothermal upwelling" phenomenological model envisages relatively shortterm, but energetic incursion(s) of thermal fluids from significant depth into the vadose zone (Szymanski \& Harper, 2002).

The "meteoric infiltration" phenomenological model, envisaging mobilization of the material from calcareous soil deposits followed by downward transport and then chemical precipitation in open cavities, is very similar to the mode of formation of speleothems. The main differences include the chemistry of the bedrock (poorly soluble volcanic tuffs), origin of the open space in which minerals were deposited (no dissolution involved), and relatively small sizes of cavities (from 5-10 $\mathrm{mm}$ for fractures to $50-80 \mathrm{~cm}$ for lithophysal 
cavities). Similarities include the postulated gravitydriven movement of water; deposition in open (air-filled) space; and important roles of meteoric precipitation (water) and soil gases $\left(\mathrm{CO}_{2}\right)$ in mineral deposition process. Similarly to speleothems, secondary minerals from Yucca Mountain are being studied to unravel paleo-hydrogeologic, paleo-environmental and paleoclimatic conditions in this part of Nevada.

The "meteoric infiltration" explanation for secondary minerals at Yucca Mountain has been proposed by scientists who have limited experience in studies of karst mineralization. Meanwhile, the karst research community represents a group from which the most authoritative opinion as to the validity of the arguments supporting this model could be obtained. Therefore, we decided to present the evidence and reasoning supporting both "meteoric infiltration" and "hydrothermal upwelling" phenomenological models to the expertise of the speleological community.

It is to be noted that the origin of secondary minerals at Yucca Mountain is far from being of purely academic concern. Yucca Mountain is a prospective site for the first in the U.S.A. geological repository of the high-level radioactive waste, which would be constructed in the vadose zone. Secondary minerals discussed in this paper provide basis for the key interpretations regarding the paleo-hydrogeology of the site. Depending on the accepted phenomenological model for these minerals, two profoundly different pictures of the past hydrogeological environment at Yucca Mountain emerge. If "meteoric infiltration" model is correct, the thick vadose zone of Yucca Mountain may safely be deemed a very stable feature, in which fluxes of infiltrating water, over the last 10-11 million years, were controlled primarily by climate. Thus, meaningful predictions of the future behavior of the hydrogeological system, as well as predictions of the performance of a nuclear waste repository placed in the vadose zone, become possible. If, however, "hydrothermal upwelling" model is correct, the paleo-hydrogeology of
Yucca Mountain would have to be considered unstable. Such scenario, if confirmed, may disqualify Yucca Mountain as a suitable site for the high-level nuclear waste disposal facility.

\section{OVERVIEW OF THE YUCCA MOUNTAIN GEOLOGY}

Yucca Mountain is a part of the Southwestern Nevada volcanic field situated in the southern part of the Great Basin. The Mountain is a north-trending horst range flanked from east and west by broad alluvial basins (Fig. 1). It is composed of a layered sequence of the Miocene (14-11.3 Ma) tuffs of rhyolitic and rhyodacitic composition, and bordered by a suite

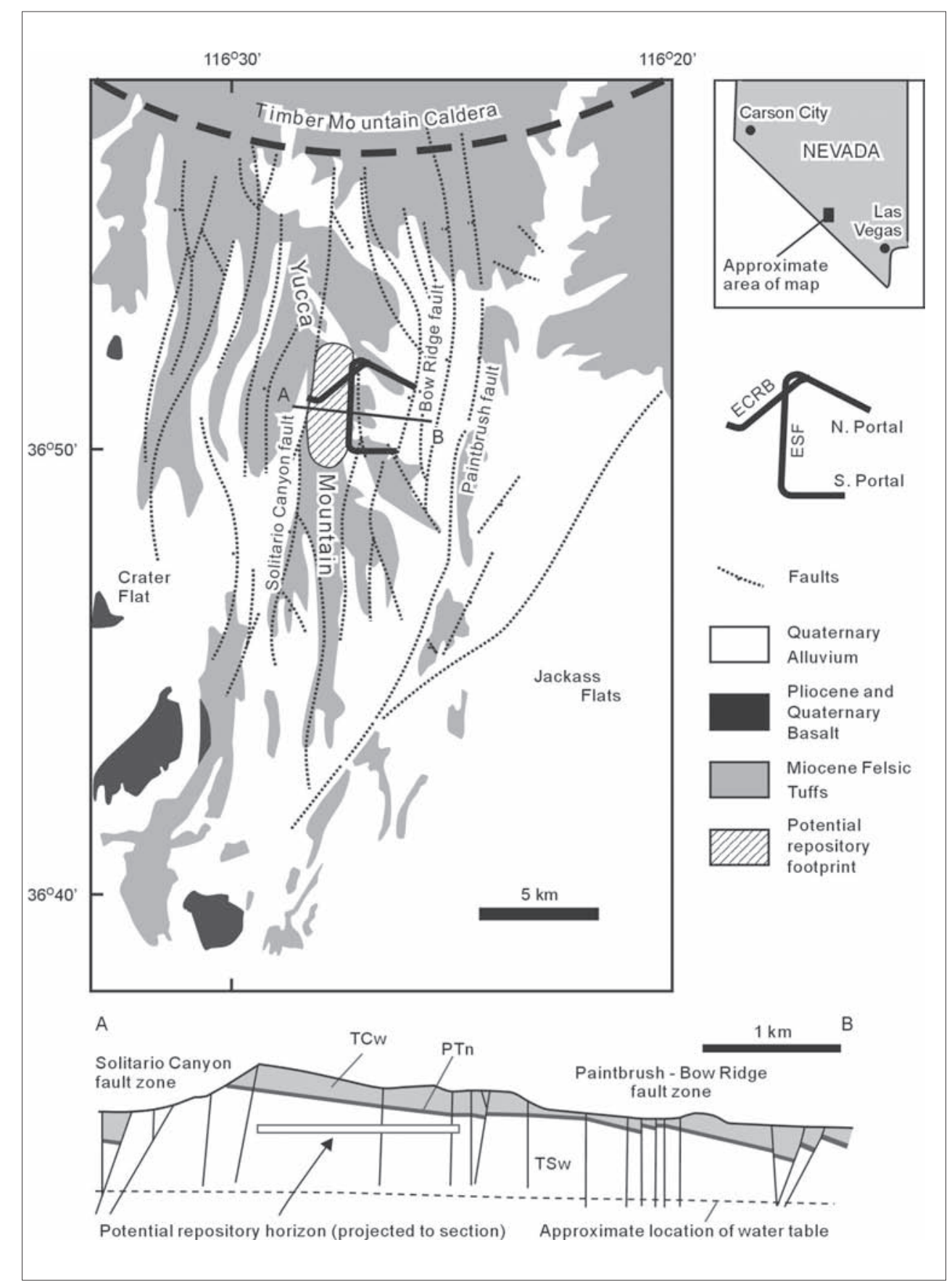

Fig. 1. Simplified geological map and cross section of Yucca Mountain, Nevada, showing approximate locations of the exploratory tunnel (ESF), the cross-drift (ECRB), and potential repository footprint. TCw - Tiva Canyon welded tuff, PTn - Paintbrush nonwelded tuff, TSw - Topopah Spring welded tuff. Modified from Day et al. (1998). 
of north-trending faults. Plio-Quaternary episodes of small-volume basaltic volcanism (from $8.5 \mathrm{Ma}$ to $0.08 \mathrm{Ma})$ resulted in a series of volcanic cones, dikes and flows located to the south and southwest of the mountain (Day et al., 1998).

The upper 400-800 meters of the Yucca Mountain Miocene volcanic sequence lie above the presentday water table and consist of a sequence of welded tuffs with subordinate amounts of non-welded to partly welded units. At depth, the Miocene volcanic rocks are underlain by Paleozoic and Late Proterozoic marine carbonates and clastics. Deep in the phreatic zone (>1000 to $1200 \mathrm{~m}$ ), rhyolitic tuffs show pervasive illite-smectite and Na-zeolitic alteration, as well as the localized deposition of fluorite, barite, quartz, and calcite. The alteration is related to a hydrothermal event that took place 10.5-11.0 Ma ago (Bish \& Aronson, 1993; Carlos et al., 1993). A hydrothermal convection system was set off at that time by a granitic magma body emplaced under the Timber Mountain caldera, some $7-9 \mathrm{~km}$ to the north of the proposed repository.

The repository would be excavated within a $\sim 150$ $\mathrm{m}$ thick layer of the welded Topopah Spring Member of the Paintbrush Tuff, some $300 \mathrm{~m}$ above the water table. A C-shaped tunnel (Exploratory Studies Facility or ESF) and a east-west cross-drift (Enhanced Characterization of the Repository Block, or ECRB) have been excavated into the proposed repository horizon (see Fig. 1).

All samples discussed in this paper have been collected from cavities intersected by these two tunnels. ${ }^{1}$

\section{MINERALOGY, ISOTOPE GEOCHEMISTRY, AND TRAPPED FLUIDS OF SECONDARY MINERALS}

Secondary mineral assemblages in cavities in rhyolitic tuffs comprise major calcite, silica minerals (quartz, chalcedony), opal, as well as accessory fluorite and zeolites (heulandite, mordenite). Rare occurrences of strontianite and barite have also been observed. The major minerals, calcite and silica, are never present in a given sample in similar proportions: one of them is always dominant while the other is subordinate. Based on this observation Smirnov \& Dublyansky (2001) defined two chemically distinct paragenetic assemblages: the silica assemblage in which different proportions of quartz, chalcedony and opal are the dominant phases and the carbonate assemblage in which calcite is the major mineral.

One of the most peculiar features of the Yucca Mountain cavity-based secondary mineralization is its "geopetal" character. In most cases mineral crusts are restricted to the floors of lithophysal cavities and

\footnotetext{
${ }^{1}$ Sample locations in the ESF and ECRB are defined by stations at 100-m intervals beginning either from the north portal of ESF or from the entrance to ECRB. For example station ESF 14+75 corresponds to $1475 \mathrm{~m}$ from north portal of the ESF.
}

near-horizontal open fractures, and to the footwalls of the steeper fractures. "Normal" veinlets in which a fracture is entirely filled with minerals are rare. Examples of mineralization occurring on the ceilings of cavities were reported only from the northeast part of the repository block, near the north portal of the ESF. Not all cavities are mineralized; as many as $90 \%$ of the lithophysae and open fractures do not contain secondary minerals (Whelan et al., 2002; Wilson et al., 2003).

\section{Mineral morphologies and textures Calcite}

Secondary calcite shows a variety of morphologies, indicative of the varying conditions of crystal growth. In breccia cements, small fissure fillings and at the bases of crusts in lithophysal cavities, calcite forms aggregates of anhedral (granular) crystals. Mineral grains do not have any specific orientation; contacts between them represent the compromise boundaries of the concurrent growth.

The outermost crystals of calcite crusts are euhedral; they may be subdivided into three broad morphologic types: platelet, bladed, and blocky (Fig. 2). A platelet morphology refers to crystals, two dimensions of which are similar and greater than the third one. In bladed crystals all three dimensions are substantially different. By contrast, blocky crystals have equant or sub-equant shapes.

The lens-shaped crystals of the platelet calcite are faced by a pinacoid $\mathrm{c}\{0001\}$ and a prism $\mathrm{m}\{10 \overline{1} 0\}$ (Fig. 2-a). Bladed is by far the most spectacular
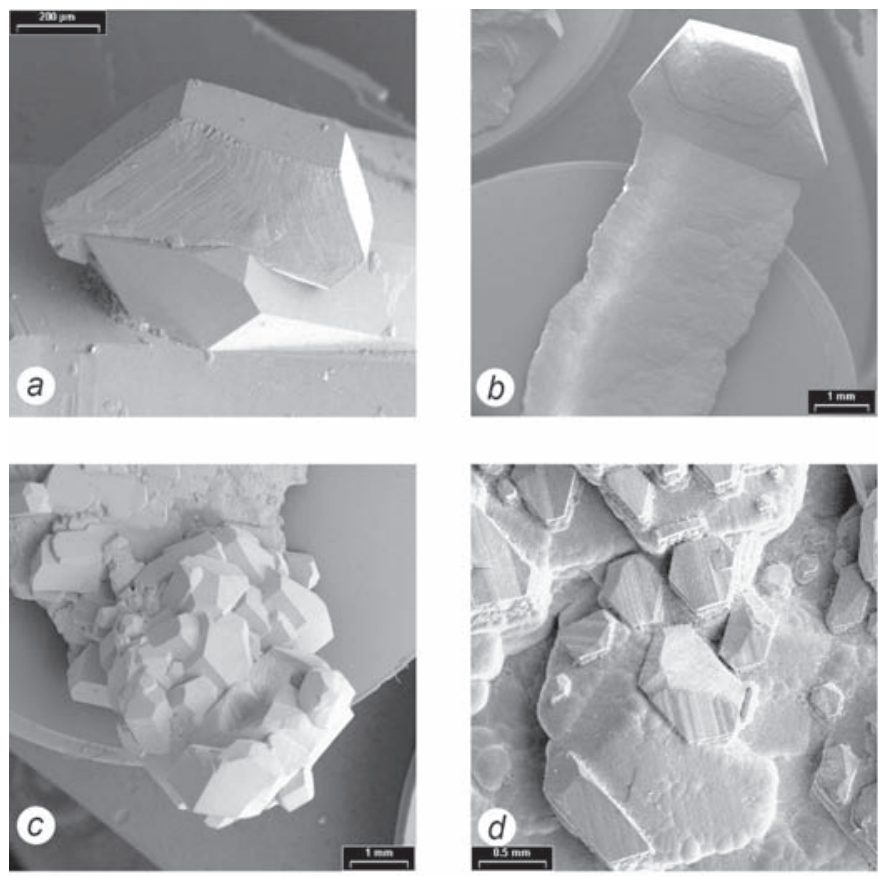

Fig. 2. SEM micro-photographs showing crystal morphology of euhedral calcite from Yucca Mountain: $a$ - thin platelet $(c+m)$, station ESF14+75; $b$ - bladed (c+m), station ESF28+80;

$c$ - prismatic $(\mathrm{m}+\delta)$, station ESF $52+43$; and $d$ - rhombohedral ( $\delta$ or $\delta+\mathrm{m}$ ), station ESF38+80 (calcite is partly coated by botryoidal opal). 
calcite morphology. Bladed calcite forms elongated crystals with a dominant pinacoid. According to the crystal symmetry of calcite, its pinacoidal section is isotropic; nevertheless bladed calcite enlarges faster in one selected direction, which makes bladed crystals similar to skeletal formations. The vector of fastest growth in bladed crystals is typically directed perpendicularly to the substratum; the freestanding crystals up to 2-3-cm-tall are formed this way (Fig. 2b). Scanning electron microscopy and optical imaging show that pinacoidal surfaces of bladed crystals carry stepped growth hillocks indicative of a dislocationcontrolled growth.

Platelet and bladed calcite commonly evolve into a scepter variety, which develops by a combination of two morphologies: platelet or blade-shaped "stem" with dominant pinacoid and blocky "head" with dominant rhombohedron $\delta\{01 \overline{1} 2\}$ and/or prism. No hiatuses between the formation of the "stem" and the scepter head were identified. Most heads show welldeveloped blocky morphology; some of them, however, exhibit the "swallow tail" morphology resulting from the preferential growth at crystal edges. Blocky calcite in scepter heads commonly precipitates together with opal, forming rhythmically zoned calcite-opal overgrowth on the bladed calcite.

Blocky morphology dominates in the outer zones of most mineral crusts studied at Yucca Mountain. Habit faces of the blocky calcite are: negative rhombohedron $\delta\{01 \overline{1} 2\}$ and prism $\mathrm{m}\{10 \overline{1} 0\}$, plus optional pinacoid c $\{0001\}$. Crystals with rhombohedral habit $(\delta+\mathrm{m})$ are most common. The prism-dominated habit $(\mathrm{m}+\delta$ or $\mathrm{m}+\mathrm{c})^{2}$ is typical of late calcite depositing together with opal. The latest calcite crystals, associated with Mg-enrichment have rhombohedral habits without prismatic faces $(\delta)$.

A generalized summary of morphologic sequences for calcite crusts from Yucca Mountain is shown in Fig. 3. In some cases mineral crusts are built up of calcite having a single, simple morphology, e.g., granular, or platelet, or blocky (Fig. 3-a, -e, and $-h$ ). The morecomplex sequences are observed in thick crusts in lithophysal cavities and low-angle fractures. The typical sequence there comprises granular calcite at the base and blocky in the outer zones; bladed calcite may be present between these two morphologies (Fig. $3-b$ through $-d$ ). In places, granular calcite is absent at the base and bladed calcite grows directly on the tuff substratum (Fig. 3-e through $-g$ ). Blocky calcite nucleates at the tips of blades or platelets to form scepters (Fig. 3- $b$ and - $f$ ); at advanced stages crystals in such aggregates acquire blocky morphology (Fig. 3- $c$ and $-g$ ), preserving in the cores, a zonation typical of bladed crystals. Importantly, the overall sequence of crystal morphology change (pinacoid $\rightarrow$ negative

${ }^{2}$ The $(m+\delta)$ morphology is known in speleological literature at the "nailhead spar" (Hill \& Forti, 1997; Onac, 1997); the type-locality for calcite with such morphology is the hydrothermal Jewel Cave in South Dakota, U.S.A. rhombohedron+prism $\rightarrow$ rhombohedron), or parts of this sequence, are consistently present in most samples collected from ESF and ECRB. This trend indicates that the conditions of calcite growth have evolved unidirectionally over the time of the deposition, on the scale of the tectonic block.

\section{Minerals of silica}

The silica in fractures and lithophysal cavities of Yucca Mountain is represented by chalcedony, quartz and opal. These varieties form two types of crusts: (1) massive crusts with fine-grained, in places spherulitic, textures; and (2) zoned crusts with spherulitic or drusy textures. The thickness of both types of crusts may reach $1 \mathrm{~cm}$. The silica minerals are more frequent in the northeast part of the repository block (near the north portal of the ESF, close to the block-bounding Bow Ridge-Paintbrush fault zone).

Quartz forms crystals, with the largest individuals reaching $1 \mathrm{~cm}$. In most instances, quartz is restricted to the earliest parts of the massive and zonal crusts, although some crystals were found growing over the latest chalcedony. In certain places, quartz forms monomineral crusts with drusy textures, or layers confined within calcite. In contrast to calcite, which in most cases occurs on the floors of cavities and footwalls of fractures, quartz grows on the walls and ceilings of the lithophysal cavities and on the hanging walls of fractures. Large quartz crystals almost always have scepter morphology.

Opal forms milky-white layers between the chalcedony-quartz layers in zoned silica-dominated crusts. In the calcite-dominated crusts, opal occurs

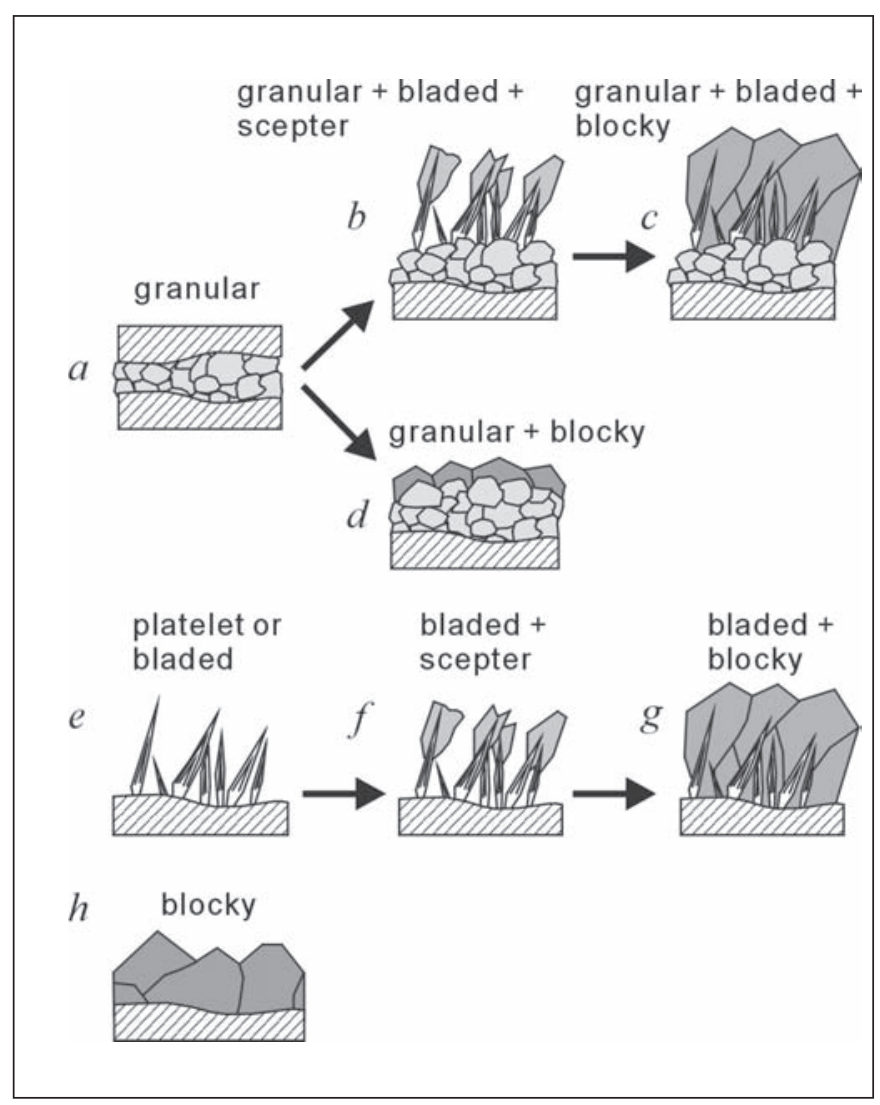

Fig. 3. Typical patterns of the morphological change in the Yucca Mountain calcite crusts. See discussion in text. 
as water-clear spherulites or botrioidal layers embedded in the calcite crystals or deposited on the calcite surface (see Fig. 2-b). The latest zones in the blocky calcite crystals, as well as the heads of scepter crystals commonly represent rhythmic calcite-opal intercalations. Most opals from the ESF contain between 50 and $280 \mathrm{ppm} \mathrm{U}$ (maximum 780 $\mathrm{ppm})$, whereas the contents of $U$ in co-genetic calcite range between $<0.01$ and $0.5 \mathrm{ppm}$ (Paces et al., 2001; Neymark et al., 2000; 2002). Formation of uraniferous opals requires extremely efficient processes of $\mathrm{U}$ uptake, which is typically realized through adsorption on colloids of silica (Zielinski, 1982).

\section{Fluorite}

Fluorite is the most common accessory mineral within Yucca Mountain. It was found in association with both the silica and the carbonate assemblages. Crystals of fluorite are typically light-violet, pinkish or colorless, with late zones typically having a more intense coloration. Fluorite occurs as aggregates of anhedral crystals, single flat- and bent-faced euhedral crystals, spherulites, and concentrically zoned oolitic colloform segregations. When different morphologic types are found within the same mineral crust, spherulitic and anhedral forms tend to dominate at the crust's base, whereas euhedral crystals are more common in the outermost parts of crusts.

\section{Zeolites}

Zeolites are the second-most widespread accessory minerals after fluorite. They were identified in samples from the ESF as heulandite and mordenite (Smirnov \& Dublyansky, 2001). In the calcite-dominated crusts, heulandite and mordenite were found in two positions: in the granular calcite at the bases of the crusts and overgrowing the bladed calcite. Heulandite was found to associate with accessory chalcedony and opal. Accessory zeolite-chalcedony intergrowths, included within bladed calcite crusts, indicate that these zeolites are either co-genetic with the bladed calcite or post-date it.

\section{Strontianite}

Although it was found only in one sample, strontianite is a mineral that undoubtedly belongs to the Yucca Mountain secondary mineralization. Numerous aggregates built up of radiating needles were found in granular calcite at ESF station $78+41$.

\section{Stable isotope properties of calcite}

Stable isotopic properties of calcite were studied within mineral individuals by means of the Laser Ablation-Gas Chromatography-Isotope Ratio Mass Spectrometry technique (Sharp, 1992; Sharp \& Cerling, 1996). The method allows for spatial resolution of about 90-200 $\mu \mathrm{m}$. Examples of the results are shown in Fig. 4. The four samples shown in the figure are from different parts of the repository block and represent different calcite morphologies; nevertheless, they exhibit remarkably similar isotopic patterns. In the process of mineral growth, $\delta^{13} \mathrm{C}$ in calcite evolved from values as heavy as +8 to +10 to -5 to $-10 \%$ PDB. Importantly, calcite with different crystal morphologies (i.e., granular, platelet/bladed, and blocky without opal) exhibit ${ }^{13} \mathrm{C}$-enrichment at early stages of growth and display "light" $\delta^{13} \mathrm{C}$ values at late stages. At the same time, $\delta^{18} \mathrm{O}$ values gradually increase with time, so that the $\mathrm{C}$ and $\mathrm{O}$ isotope properties are negatively correlated $(\mathrm{R}=-0.7$ to -0.9$)$.

The latest variety - rhombohedral blocky calcite with opal - seems to be a partial exception from general isotopic trend. As a group, it occupies the "low $\delta^{13} \mathrm{C}$-high $\delta^{18} \mathrm{O}$ " corner of the cross-plot and by doing so, conforms to the trend. Within the group,

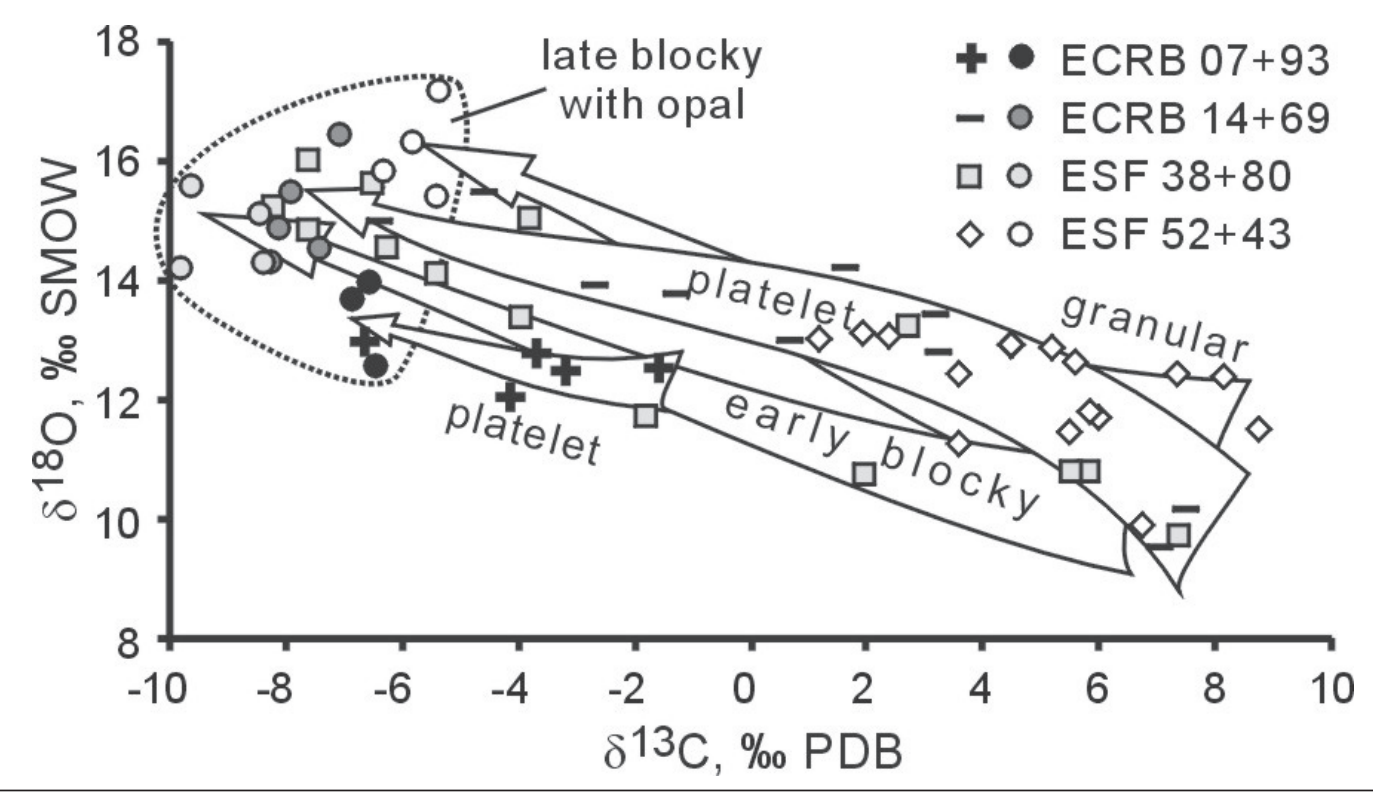

Fig. 4. Systematic change of stable isotopic properties in calcite with different morphologies. Four calcite samples were studied along crystallographically defined directions. Overall directions of growth is shown by arrows. Each of four samples exhibits evolution of crystal morphology. Early calcite is represented by granular, platelet, platelet+scepter, or blocky morphologies (cf. Fig. 3). The latest morphologic variety in all four samples is blocky calcite with opal (circles). 
however, a negative correlation between carbon and oxygen is absent, which suggests a significant change in the physico-chemistry and, possibly, the mechanism of mineral growth at this time.

\section{Fluid inclusion studies \\ Paleo-temperatures}

Fluid inclusion assemblages (FIA's) suitable for paleo-thermometric studies were found in $\sim 50 \%$ of calcite samples, as well as in a number of fluorite and quartz samples from the ESF and ECRB (Dublyansky et al., 2001; Whelan et al., 2003b; Wilson et al., 2003). In many instances primary character of these inclusions can be ascertained, because they are developed along the growth zones of the host minerals. In this case, the measured $\mathrm{T}_{\mathrm{h}}$ 's closely correspond to the temperature at which this part of mineral grew. Two-phase inclusions in FIAs studied from calcite, quartz and fluorite yielded generally consistent $T_{h}$ 's, although temperatures measured in some fluorite samples were somewhat higher and more scattered. This likely reflects post-depositional stretching of inclusions, which makes paleo-temperature estimates from fluorite less reliable. By contrast, thermometric data from calcite are very consistent: the $T_{h}$ 's measured in tens of inclusions from individual FIA's commonly showed as little scatter as $4-8^{\circ} \mathrm{C}$.

The temperatures were greater at early stages of mineral growth $\left(\sim 60\right.$ to $\left.85^{\circ} \mathrm{C}\right)$ and declined with time. Most late-stage calcites contain only all-liquid inclusions, suggesting temperatures less than $~ 35-$ $50^{\circ} \mathrm{C}$. Examples of the fluid inclusion data are shown in Fig. 5. Temperatures measured in early calcites are not uniform on the scale of the repository block. Minerals collected close to the Bow Ridge fault (a splay of the major horst-bounding Paintbrush fault) near north and south portals show the highest temperatures (Fig. 5-d). The temperatures decrease westward and attain minimum values in the central part of the repository block.

\section{Salinities}

The fluid salinities calculated some 150 measurements of freezing depression temperatures ranged from <0.18 wt. \% (conventional detection limit for the freezing method, corresponding to the ice melting temperature of $-0.1^{\circ} \mathrm{C}$ ) up to $2.71 \mathrm{wt}$. \% $\mathrm{NaCl}-$ equivalent (Dublyansky et al., 2001; Wilson et al., 2003). The mineral-forming waters, thus, span the fresh water, the brackish water, and the saline water hydrochemical classes (Davis \& DeWiest, 1966).

\section{Gas chemistry}

Calcite, fluorite and quartz at Yucca Mountain commonly contain monophase gaseous inclusions. This indicates that crystal growth occurred from a heterogeneous fluid, composed of two immiscible phases - liquid (water) and vapor (some gas and/or water vapor). Some 24 all-gas and gas-rich inclusions in five samples of calcite and one sample of quartz were analyzed using a Dilor Raman spectrometer with Ar laser. In most instances, inclusion gases yielded

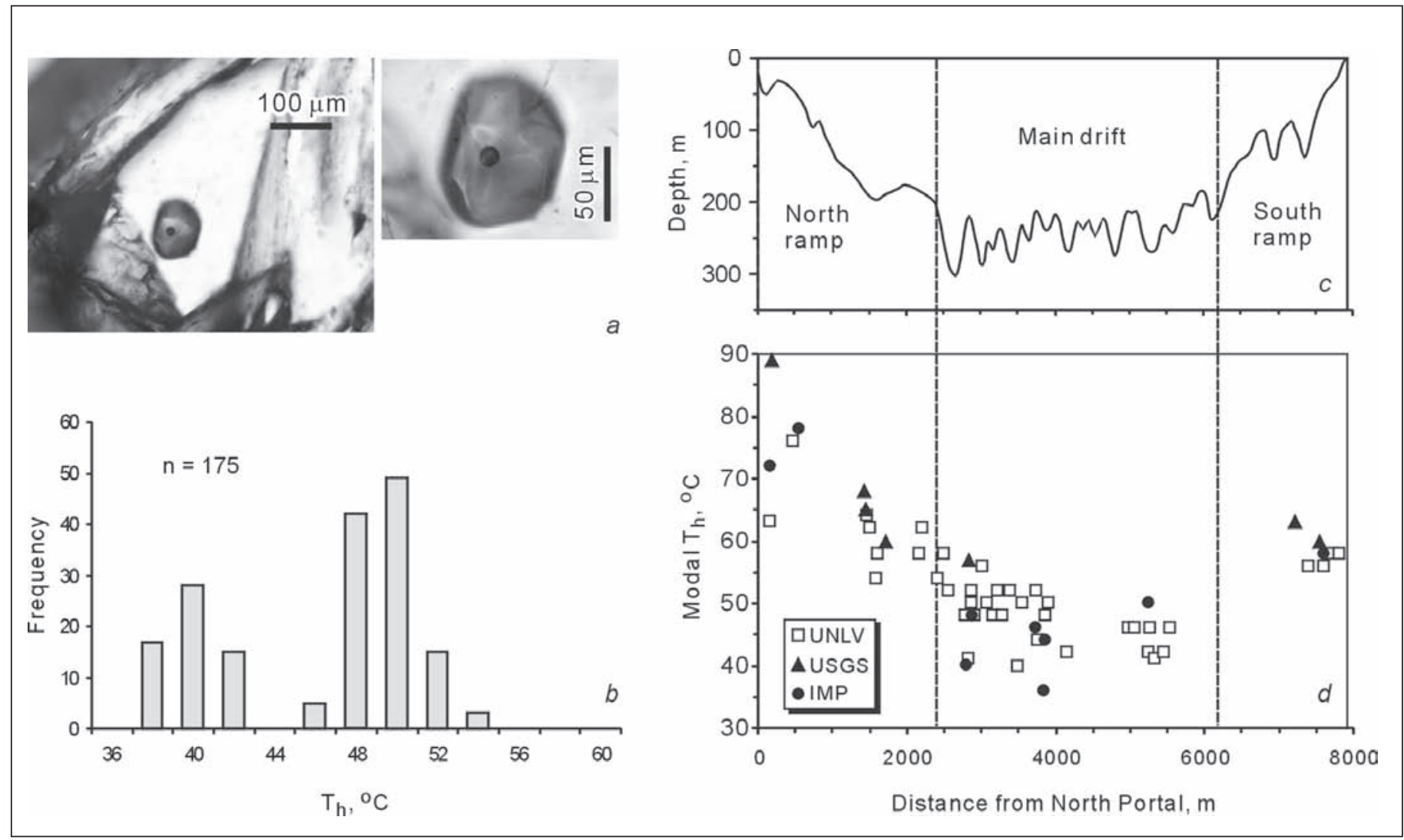

Fig. 5. Fluid inclusion thermometric data from secondary calcite: a - Micro-photograph and close-up view of primary two-phase inclusion in bladed calcite (ESF station ESF station 12+91); $b$ - Homogenization temperatures in calcite sample from ESF station 12+91; $c$ - depth from earth surface of the ESF; and $d$ - Distribution of maximum $\mathrm{T}_{\mathrm{h}}$ 's in samples from ESF. The data shown on the graph represent modal values calculated for the data obtained from tens to hundreds of individual inclusions in each sample. The data sources: UNLV - Wilson et al. (2003), USGS - Whelan et al. (2003b), and IMP - Dublyansky et al. (2001). 
broad humps on Raman spectra (400 to $4500 \mathrm{~cm}^{-1}$ ) characteristic of fluorescence, while matrix (calcite and quartz) did not fluoresce (Dublyansky, 2001). Fluorescence of fluid inclusions in Raman studies is typically caused by the presence of cyclic and aromatic hydrocarbons (Burke, 2001).

Levy et al. (1995) studied composition of gases released from inclusions in two calcite samples from ESF by means of the Quadrupole mass-spectrometry (bulk analysis of gas- and liquid dominated inclusions). The major constituent was $\mathrm{H}_{2} \mathrm{O}(99.92$ to $99.96 \mathrm{~mol} \%) . \mathrm{CO}_{2}$ and $\mathrm{CH}_{4}$ were present in similar proportions $\left(\mathrm{CO}_{2}=1.6 \cdot 10^{-2}\right.$ to $1.2 \cdot 10^{-1} \mathrm{~mol}$ $\%$ and $\mathrm{CH}_{4}=1.3 \cdot 10^{-2}$ to $9.0 \cdot 10^{-2} \mathrm{~mol} \% ; \mathrm{CO}_{2} / \mathrm{CH}_{4} \approx$ 1.5), whereas contents of $\mathrm{O}_{2}$ were significantly lower (9.6 $10^{-3}$ to $\left.3.2 \cdot 10^{-2} \mathrm{~mol} \%\right)$.

\section{Isotope properties of paleo-waters}

Wilson et al. (2003) reported ten $\delta$ D measurements of waters released from fluid inclusions from three calcite samples. The data are plotted in Fig. 6 along with the respective $\delta^{18} \mathrm{O}_{\text {water }}$ values calculated from $\delta^{18} \mathrm{O}_{\text {calcite }}$ and $\mathrm{T}_{\mathrm{h}}$, from the same samples (Dublyansky \& Smirnov, 2003). Most of the data plot to the right of both the modern-day Nevada Meteoric Water Line and the line inferred for Nevada's cooler Pleistocene climate. The data from paragenetically intermediate calcite plot to the left and above the lines.

\section{THE TWO GENETIC MODELS FOR SECONDARY MINERALS AT YUCCA MOUNTAIN}

\section{"Meteoric infiltration" model}

At early stages of the Yucca Mountain studies, it was found (in samples from borehole cores) that fractureand open cavity-lining calcite from the vadose zone is different in terms of its stable ( $\mathrm{C}$ and $\mathrm{O}$ ) and radiogenic (Sr) isotope compositions from calcite that occurs in the deeper phreatic zone. At the same time, its isotopic properties were found to be similar to those of the micritic calcite veins and slope-parallel deposits developed at the surface of Yucca Mountain. Since the hydrothermal origin of the deep-seated phreatic-zone calcite was known (e.g., Bish \& Aronson, 1993), and the pedogenic origin of the surface calcite-silica deposits was by that time vigorously publicized (e.g., Quade \& Cerling, 1990; Stuckless et al. 1991; Peterman et al., 1992), these isotopic observations were used to assign the vadose-zone calcite a non-hydrothermal origin. It was hypothesized that the mineral crystallized from the meteoric water that percolated through the fractures in the vadose zone and carried dissolved material from the overlying carbonate-rich soil (e.g., Szabo \& Kyser, 1990, Whelan \& Stuckless, 1991; Peterman et al., 1992; Vaniman, 1993; Roedder et al., 1994; Whelan et al., 1994). This concept has won official endorsement of the U.S. DOE, and presently serves as one of the cornerstones of the Yucca Mountain safety case (DOE, 1998; 2001).

The line of reasoning presented above contains an obvious logical flaw. The fact that the vadose-zone calcite is different from calcite produced in the course of the deep-seated hydrothermal circulation does

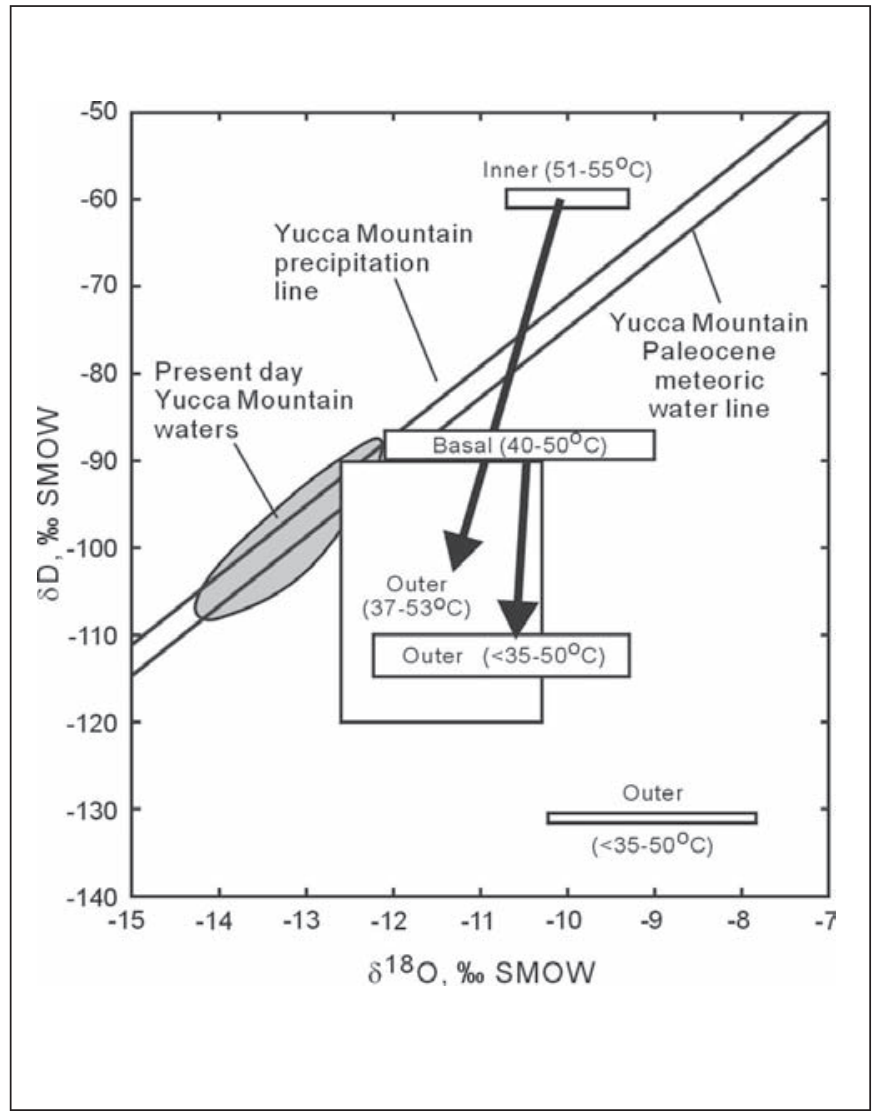

Fig. 6. Boxes enveloping measured $\delta \mathrm{D}$ and calculated $\delta^{18} \mathrm{O}$ values of waters trapped in inclusions in the Yucca Mountain calcite compared with different types of the present-day waters from the Yucca Mountain region, as well as with the present-day and the inferred Paleocene Meteoric Water Lines for Nevada. Arrows connecting boxes indicate the direction of isotopic change with time in individual samples. "Inner", "basal" and "outer" reflect the relative position of the analyzed calcite in the mineral crust. The graph is constructed from the data reported in Wilson et al. (2003). Data for the present-day Yucca Mountain waters are from Yang et al. (1996). Modern Nevada precipitation line is by Benson \& Klieforth (1989); Paleocene water line is by Meijer \& Kwicklis (2000). The $\delta^{18} \mathrm{O}$ for paleo-waters were calculated from measured $\delta^{18} \mathrm{O}$ and $\mathrm{T}_{\mathrm{h}}$ values of host calcite using fractionation equation by Kim \& O'Neil (1997).

not necessarily mean that the vadose-zone calcite is formed by meteoric infiltration.

Among the arguments, used at early stages of research in support of the "meteoric infiltration" origin of the vadose zone calcite were, for example: "(1) the lack of any visible fluid inclusions that often form in calcite at high temperatures; (2) the absence of minerals in the tuffaceous wall rocks that would indicate the fluids were hydrothermal; ... " (Szabo \& Kyser, 1990, p. 1717). Ironically, both of these contentions were later proven to be wrong: secondary quartz, calcite and fluorite (all typical hydrothermal minerals) sampled in the ESF were found to contain two-phase fluid inclusions, yielding elevated homogenization temperatures (up to $85-90{ }^{\circ} \mathrm{C}$; Dublyansky et al., 2001, Wilson et al., 2003; Whelan et al., 2003b). In addition, later finer scale studies have demonstrated that the spectrum of isotopic properties of the vadosezone calcite is wider than that of the both, surface 
calcite and the phreatic-zone hydrothermal calcite. Although these findings virtually eliminated the initial basis of the "meteoric infiltration" interpretation, the latter concept endured.

New arguments, developed as more exposures of secondary minerals become available for inspection after construction of the $7.8 \mathrm{~km}$-long ESF tunnel include the following observations (Paces et al., 2001; Whelan et al., 2002): (1) Secondary mineral deposits are restricted to the footwalls of steep fractures and to the floors of lithophysal cavities and low-angle fractures; this has been interpreted as an expression of gravity control on the movement of water films, from which the minerals purportedly grew; and (2) Secondary minerals occur in only small part (less than ca. $10 \%$ ) of open fractures and lithophysal cavities; most of the potential depositional sites are barren; mineralized and non-mineralized are commonly intersect or are in close proximity. The subsequent description of the "meteoric infiltration" phenomenological model is based on publications by Paces et al. (2001) and Whelan et al. (2002).

According to the model, percolation occurred through the interconnected fractures in welded tuffs and the pore space in non-welded tuffs of the vadose zone. The water moved along preferential pathways as meandering and fingering films. Escape of $\mathrm{CO}_{2}$ into the gas phase and evaporation of water are cited as two controlling mechanisms for deposition of calcite. Silica deposition is believed to be controlled solely by evaporative concentration of the solutions, which was partly countered by increasing solubility of silica with depth due to increasing temperatures. Open space is considered to be an important part of depositional process, since it fosters separation of gases as well as facilitates their upward removal from depositional sites. During downward percolation of waters, calcite solubility was exceeded either by warming in response to the geothermal gradient $\left(\mathrm{CO}_{2}\right.$ solubility decreases with increasing temperature) or by evaporative concentration. The model, therefore, envisages downward, gravity driven movement of liquid phase (water) and upward, temperature (buoyancy) driven movement of gas phase (exsolved $\mathrm{CO}_{2}$ and evaporated $\mathrm{H}_{2} \mathrm{O}$.

\section{"Hydrothermal upwelling" model}

An alternative model explains the origin of secondary minerals by the short-term incursion(s) of the deep-seated thermal waters into the vadose zone of Yucca Mountain (Szymanski \& Harper, 2002). The most important observation that led to this interpretation was the discovery the elevated depositional temperatures (up to $85^{\circ} \mathrm{C}$ ) for these minerals. Later studies unraveled other geochemical features indicative of the deep-seated provenance of mineral-forming fluids (e.g., Dublyansky et al., 2003). The model envisages deposition of minerals in the phreatic (subaqueous) environment; it will be described in more details at the end of the paper.

\section{DISCUSSION OF THE EVIDENCE: IS IT CONSISTENT WITH "METEORIC INFILTRATION" OR "HYDROTHERMAL UPWELLING" ORIGIN?}

\section{Morphological and textural evidence}

A very unusual morphology of crystal aggregates, combined with their nearly exclusive appearance at the cavity floors (geopetal character), makes the Yucca Mountain vadose zone deposits a truly unique mineralogical curiosity. We are not aware of any descriptions of similar deposits in the mineralogical literature. Nevertheless, in order to understand the paleo-hydrogeology of Yucca Mountain, the setting and the mode of formation of these deposits must be deciphered.

\section{Geopetal appearance}

One of the most striking features of the calcite-silica deposits in the ESF is their occurrence at the floors of cavities and footwalls of fractures, which suggests that deposition of the minerals was affected by the force of gravity. Geopetal appearance was interpreted as an indication of crystallization in the vadose zone from gravity-driven films of water, and considered as the strongest argument supporting the "meteoric water" origin of the deposits (Paces et al., 2001; Whelan et al., 2002). It should be noted, however, that gravity control, expressed as crystallyzation on the upward-facing surfaces is a feature known from phreatic environments - both hydrothermal and low-temperature (e.g., Yushkin, 1966; Grigoriev \& Zhabin 1975; Dublyansky, 1995). Examples are shown in Fig. 7.

Chemical reactions controlling deposition of calcite are not subject to the control of gravity per se; in phreatic environment, the force of gravity may control places where crystal growth begins and continues. In order to explain geopetal appearance of mineral aggregates at Yucca Mountain two observations are important: (a) growth of such aggregates commonly begins from anhedral granular calcite (see Fig. 3); and (b) in many samples early granular calcite contains large primary (comparable to the size of crystal individuals) monophase gaseous inclusions. These observations indicate that at early stages of the development of aggregates growth occurred from strongly oversaturated solution (fast nucleation, competition between multiple growing crystals) and in heterogeneous (liquid+vapor phases) medium.

Nucleation of a mineral may occur due to the abrupt change of the saturation state of the fluid. For calcite this may be caused by effervescence of dissolved $\mathrm{CO}_{2}$ in response to a rapid pressure drop occurring when water moving through a thin fracture enters a cavity, or in response to vibratory motions during an earthquake. If effervescence is vigorous enough, tiny crystal nuclei may form in the bulk of the fluid (homogeneous nucleation) as well as on the gas bubbles or solid particles (heterogeneous nucleation). In a strongly supersaturated solution, nuclei may quickly become large enough so that they sedimentate under the force of gravity. Nucleation of calcite on $\mathrm{CO}_{2}$ bubbles, subsequent crystal growth and entrapment of the 


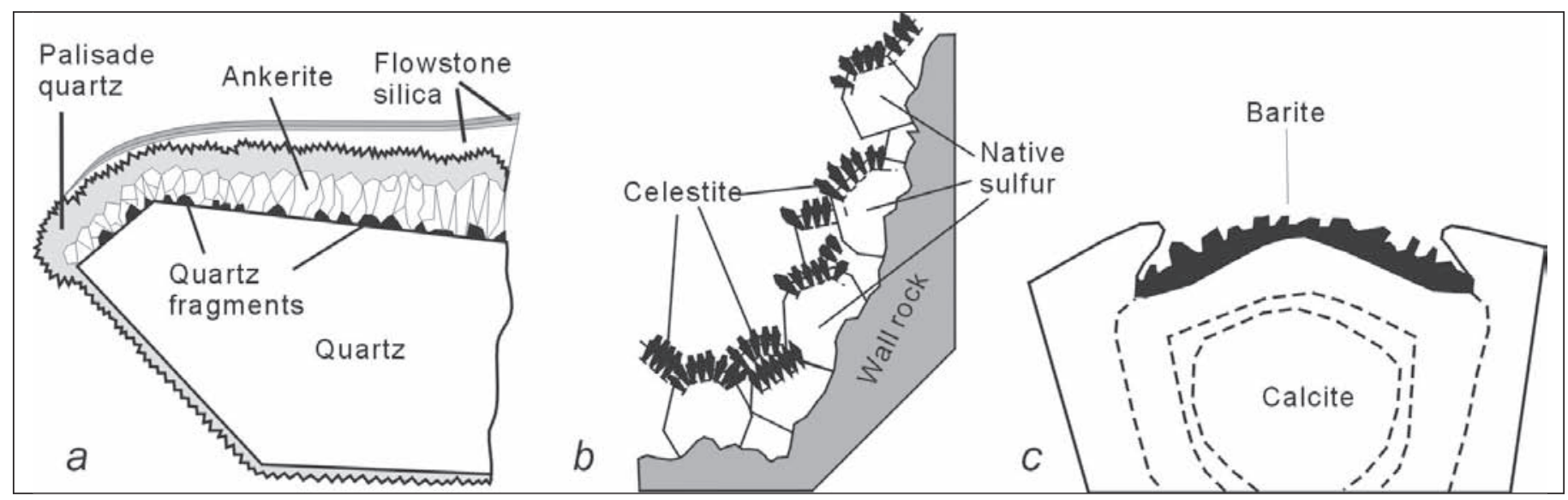

Fig. 7. Examples of gravity-controlled crystal growth in the hydrothermal and low-temperature phreatic environment. a - Hydrothermal quartzankerite assemblage, Urals, Russia (from Grigoriev \& Zhabin, 1975), b - Low temperature gypsum-sulfur deposit Shor-Su, Turkmenistan (from Yushkin, 1966), and $c$ - Barite "shielding" the surface of a scalenohedral calcite crystal, Mátiás-hegy hydrothermal cave, Budapest, Hungary (from Dublyansky, 1995). Note that crystals of ankerite $(a)$, celestite $(b)$ and barite $(c)$ grow only on the upward-facing surfaces of earlier crystals (quartz, native sulfur and calcite, respectively).

bubble was experimentally studied by Aquilano et al. (2003). Nucleation on bubbles created by mechanical agitation and $\mathrm{CO}_{2}$ degassing is believed to be a leading factor in formation of tuffaceous speleothems in turbulent gravitational water streams (Self \& Hill, 2003). The latter mechanism, although providing physical explanation for both granular textures and the entrapment of gaseous inclusions, is not an exact analog of the process that was likely responsible for deposition of calcite at Yucca Mountain. In turbulent flow environment, the heterogeneous nucleation mechanism operates continuously, leading to continuous formation of new nuclei, which precludes from growth competition between these crystals. At Yucca Mountain the excursion of the mineral-forming solution into the oversaturated state likely represented a single abrupt event. At later stages of growth, the oversaturation decreased, so that euhedral crystals began to develop (see Fig. 3).

Geopetal occurrence of opal is also perfectly compatible with the phreatic setting. Deposition of opal from colloidal solutions involves enlargement, coagulation, and sedimentation of colloidal particles (micelles) of silica. Thus, gravity is expected to play an important role in distribution of opal. By contrast, quartz crystals at Yucca Mountain are commonly found also on ceilings of cavities and on hanging walls of fractures. This reflects the difference in deposition mechanism. Nucleation and crystallization of quartz is unaffected by the pressure variations and degassing (calcite), or coagulation of colloids and sedimentation (opal). Location of quartz crystals in different positions on the walls of voids indicates that it grew from ionic solutions and that the overall flux of the matter was directed toward the walls of the voids. Such a growth mechanism requires that cavities are completely filled with the solution.

\section{Crystal morphology}

The vadose-zone calcite crystals depositing in the ambient-temperature caves (speleothems) have a characteristic rhombohedral (with dominant sharp rhombohedron $\varphi\{02 \overline{2} 1\})$ and scalenohedral morphology
(Onac, 1997). The first form is extremely rare in the Yucca Mountain samples, whereas the second one has not been observed at all. Climate or other variations of natural parameters controlling chemistry and availability of the mineral-forming solutions may exert control on the fabric of speleothems (e.g., Frisia et al., 2000), but are not known to affect crystal morphology of the speleothemic calcite. Calcite from Yucca Mountain exhibits spectacular transition from platelet crystals with dominant pinacoid to the rhombohedral and prismatic crystals (Fig. 8-a). Many researchers described such a morphologic sequence as a typical one for hydrothermal deposits from around the world (e.g., Kalb, 1929; Sunagawa, 1953; Aliev, 1966; Fig. 8-b). Such morphologic trend is thought to develop in response to decreasing temperature and $\mathrm{pCO}_{2}$ (Krasnova \& Petrov, 1997).

\section{Textures}

Textures change in response to changing conditions of mineral growth. Granular texture, commonly found at the bases of the Yucca Mountain crusts, indicates that a large number of crystals nucleated virtually simultaneously. There was not enough free space in the zone where the crystals grew, so that euhedral crystals could not develop and anhedral crystals formed instead. Only the outermost crystals in granular aggregates acquired crystallographic shapes. In contrast to granular calcite, the number of nucleation events that occurred at the inception of blocky and platelet crystals was relatively small, so that the forming crystals had enough free space to develop crystallographically defined faces. (Crystals growing on the granular calcite substratum may not require new nucleation events).

The transition from granular to euhedral morphology indicates the change in the nucleation rate, which is closely related to oversaturation in the system and typically decreases with decreasing oversaturation (Chernov et al., 1980). This implies that in order to produce complex textures, such as those shown in Fig. 3 for example, the mineral-forming solution must have experienced significant change in its saturation state. 


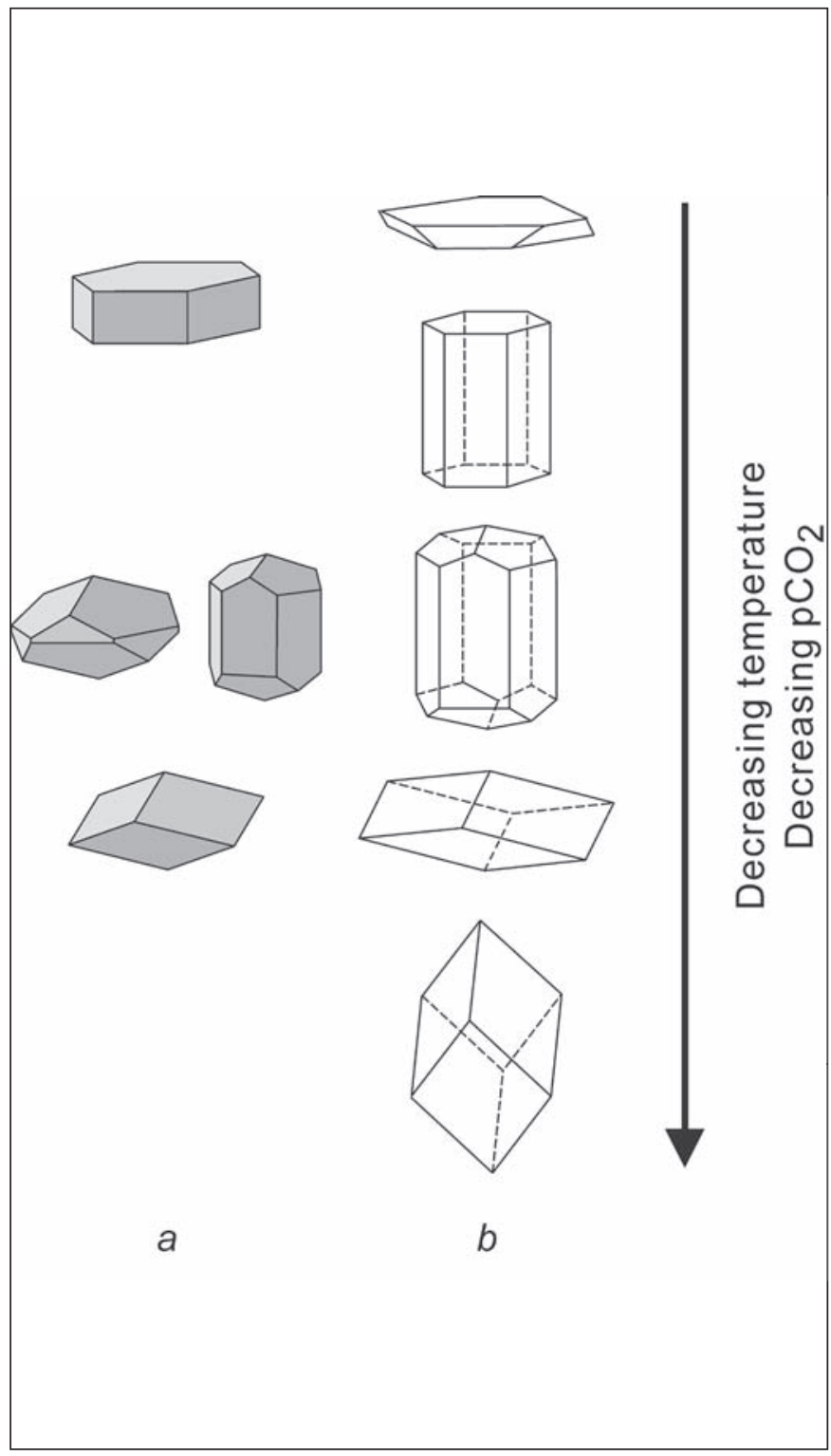

Fig. 8. Morphological sequence of Yucca Mountain calcite (a) compared with general trend of habit change reported for hydrothermal calcite ( $b$ compiled from Kalb, 1929; Aliev, 1966; and Ikornikova, 1975).

A consistent, on the tectonic block-scale, overall pattern of textural changes may be interpreted as an indication of an overall decrease in the degree of oversaturation in the course of the mineral growth, caused by the overall evolution of the mineral-forming system. Importantly, this evolution was unidirectional, rather than cyclic or oscillating, as would be expected if climate-related processes (e.g., infiltration of surface waters) were involved in mineral deposition.

Since according to the "meteoric infiltration" model mineral-forming solutions moved through fractures of Yucca Mountain as aqueous films (Paces et al., 2001; Whelan et al., 2002), an important supporting evidence for this model would be the identification of mineral textures characteristic of the deposition in vadose environment. Importantly, such common telltale textures of vadose cementation as meniscus and pendant textures are absent from the Yucca
Mountain deposits. Many lithophysal cavities and some early fractures have a selvage composed of 0.1 to $1.0 \mathrm{~mm}$-tall crystals of tridymite and quartz related to the syngenetic vapor-phase alteration of tuffs. These selvages, as well as aggregates of secondary calcite crystals represent quite rugged micro-relief with abundant and deep reentrants between adjacent crystals. On such a substratum, the appearance of the meniscus textures, reflecting the surface tension phenomena, would seem to be inevitable if water films were indeed involved in crystallization.

\section{Scepter morphology}

As was noted earlier, both calcite and quartz crystals at Yucca Mountain commonly exhibit scepter morphology. For calcite, a drastic change in the anisotropy of the growth rate is required in order to produce a change in the pattern of growth from predominantly bladed to blocky scepter morphology. This can only be caused by an equally drastic change in the conditions of mineral deposition. In addition, preferential growth at the crystal edges in scepter heads, reflected in the "swallow tail" morphology, suggests that the process of the growth at these stages was controlled by diffusion rather than by kinetics of chemical reactions.

Crystallization of the scepter calcite is associated with the transition from the pinacoidal habit to the rhombohedral one, which is a typical feature of hydrothermal calcite in general (see Fig. 8). The late stages of scepter crystallization likely occurred at low oversaturation state. Scepter morphology of quartz crystals reflects the transition from the longprismatic form to the short-prismatic one. Such gradation toward the isometric shapes may also be related to decreasing oversaturation. The mechanism of the scepter growth of quartz crystals involves the inception of growth layers near the crystal tips and a slowing down of their development as they propagate toward the base of the crystal. Growth layers come to a complete stop forming terminal steps well before they reach the base of the crystal. Such morphology also indicates a supply of matter controlled by diffusion.

\section{Discussion of the USGS model}

A specific model was proposed by Paces et al. (2001) and Whelan et al. (2002) to explain the unusual blade-shaped morphology of calcite crystals. These authors proposed that: (1) the calcite blades and associated opal precipitated from water films that were drawn up crystal faces by surface tension, and (2) the bladed morphology of crystals resulted from enhanced evaporation at crystal edges and corners where capillary films bend, and the curvature of the water film surface increases the saturated water vapor pressure (the Laplace pressure effect).

We perceive a number of serious problems with this depositional model. First of all, the model is incomplete; a number of critically important components are missing from it. For example, while addressing the question of how the mineral forming solution was brought to the tops of the already-existing bladed crystals, the model does not explain how these elongated (up to $3 \mathrm{~cm}$ in size) crystals have formed 
in the first place. Also, the model address only the bladed calcite morphology; other textures commonly observed in the Yucca Mountain samples, such as anhedral, blocky, or short-bladed calcite aggregates in which crystals are oriented randomly in 3-D space, do not appear to be readily explainable by the proposed mechanisms. Yet, on the basis of their geochemistry, these different types of calcite appear to be identical.

Describing the characteristic textures of speleothems, Kendall \& Broughton (1978, p. 519) provided a simple and logical explanation why large euhedral freestanding crystals do not form in such a setting: "... distinctive fabrics of palisade calcite are formed because precipitation usually occurs from thin water films that flow over the growing speleothem surfaces. Large crystal terminations do not form on the speleothem surface because they form projections that disturb the water flow away from the projections which, as a consequence, are gradually eliminated." From the standpoint of the theory of crystal growth, large euhedral calcite and quartz crystals must form in a submerged state because molecules that build the crystal lattice must be supplied uniformly to all crystal faces at a steady low rate (Sunagawa, 1982). The presence of euhedral crystal terminations in calcite cements is considered in sedimentary petrology as indication of cementation occurring in phreatic environment (e.g., Goldstein \& Reynolds, 1994). Calcite with bladed morphology, however, is not very common in diagenetic cements; by contrast, such calcite is commonly found in hydrothermal systems where it is considered as mineralogic indication of boiling and/or $\mathrm{CO}_{2}$ degassing (Moore et al., 2001; Etoh et al., 2002).

Whelan et al. (2002, p. 746) support the mechanism of growth proposed for the elongated bladed crystals (surface tension-related lifting of water and evaporation) by stating that "Several types of subaerial speleothems have been attributed to water films that were drawn up their outer surfaces by surface tension and evaporated from crystal tips (Hill and Forti, 1997)." This account does not seem to be technically accurate. The three out of the four types of speleothems cited by Whelan et al. (2002) (cave bubbles, cave caps and subaerial coralloids) are clearly irrelevant as examples. First, having suggested the upward capillary movement of water for cave bubbles and cave caps, Hill \& Forti (1997) did not claim that the draw of water occurred "up their outer surfaces". These speleothems are polycrystalline aggregates consisting of a multitude of tiny calcite crystals. As a consequence, they possess intercrystalline porosity, which allows capillary movement of water within this pore space. Second, discussing the depositional mechanisms for subaerial coralloids, Hill \& Forti (1997, p. 60) proposed, among other possibilities, their formation "by waters moving upward from pools onto walls by capillary action" (i.e., the water moves up the walls of caves, not the outer surfaces of coralloids). Coralloids are also polycrystalline and porous, so the water readily seeps through them, due to capillarity, as was experimentally demonstrated by Moore \& Sullivan (1964). The fourth type of cave deposits cited by Whelan et al., (2002), anthodite ("radiating, spiky, quill-like sprays of crystals") consists of the monocrystalline stalks, and therefore, it appears to be more relevant to the Yucca Mountain case. Its origin however, is still not well understood. Hill \& Forti (1997) cautioned: "Anthodites are thought to grow by thin films moving by capillary action over the surface of needle stalks and/or through the central tubes, but it should be emphasized that the origin of anthodites has never been demonstrated." (p.47).

Calcite from Yucca Mountain exhibit important dissimilarities from speleothems, which are believed to grow by evaporation in a capillary film environment; relevant examples are branching aggregates, such as corallites and crystallictites. The latter might be considered as the closest analog of the Yucca Mountain bladed calcite, because crystallictites are built from faced crystals (Serban et al., 1961). Crystallictites, however, are typical of aragonite and gypsum, but not of calcite, because in cave environment crystals of the latter have strong tendency of splitting, leading to formation of corallites (Self \& Hill, 2002). The later authors describe the mechanism of growth of branching aggregates as follows: "Molecules of solvent (water vapor and $\mathrm{CO}_{2}$ ) leaving one branch adhere to neighboring branches, thus slowing their growth. For this reason, competing branches newer touch each other and the strongest growth is always out towards the open void of the cave ..." (p. 138). By contrast, bladed crystals at Yucca Mountain are commonly in lateral contact with each other, and in many occurrences they are capped by a layer of late blocky calcite with opal (see Fig. 3-c and $-g$ ). Also in striking contrast with the Yucca Mountain mineralization, geopetal occurrence is not characteristic of the branching aggregates or anthodites. Anthodite stalks develop at different angles to the cave walls, commonly on protrusions, i.e., in positions fostering evaporation (Hill \& Forti, 1997). Subaerial coralloids in many cases grow roughly perpendicularly to the gravity force (Dublyansky \& Pashenko, 1997).

\section{Geochemical evidence \\ The ${ }^{13} \mathbf{C}$-enriched calcite}

Calcite from early parts of the Yucca Mountain crusts commonly shows strong enrichment in ${ }^{13} \mathrm{C}$ isotope $\left(\delta^{13} \mathrm{C}\right.$ up to $+10 \%$ PDB). Such values are not very common for terrestrial authigenic carbonates. Carbon is a minor component in the mineral forming fluid. In the temperature range from 20 to $100^{\circ} \mathrm{C}$ it shows very little fractionation, so that its isotopic composition in hydrogenic calcite is controlled primarily by compositions of the sources that supply carbon into the mineral forming solution. Within the "meteoric infiltration" model, the potential carbon sources are limited and their isotope properties are fairly well constrained. Those are: (1) the calcareous deposits at the surface $\left(\delta^{13} \mathrm{C}=-8\right.$ to $-3 \%$; DOE, 1993); (2) atmospheric $\mathrm{CO}_{2}\left(\delta^{13} \mathrm{C}=-6 \%\right.$; characteristic preindustrial value); and (3) soil $\mathrm{CO}_{2}$ and gaseous $\mathrm{CO}_{2}$ from the vadose zone $\left(\delta^{13} \mathrm{C}=-9\right.$ to $-26 \%$; Thorstensen 
et al., 1989; McConnaughey et al., 1994; Yang et al., 1996). Calcite crystallizing from water isotopically equilibrated with these carbon "reservoirs" would have $\delta^{13} \mathrm{C}$ values ranging between ca. -11 and $+1 \%$ o PDB. The formation of calcite with more positive $\delta^{13} \mathrm{C}$ values, thus, requires other explanation.

Natural environments from which the ${ }^{13} \mathrm{C}$-enriched carbonates were reported include travertines (Gonfiantini et al., 1968), calcite cements from bacterial methanogenic environments (Talma \& Netterberg, 1983; Budai et al., 2002), and carbonate gangue minerals in some hydrothermal deposits (Rye \& Ohmoto, 1974).

Travertine mechanisms. Two mechanisms are believed to cause ${ }^{13} \mathrm{C}$ enrichment in travertines. One mechanism is progressive escape of the ${ }^{13} \mathrm{C}$-depleated $\mathrm{CO}_{2}$ from solution into the gas phase during flow of waters away from discharge points. This leads to the respective enrichment of the remaining dissolved carbon in ${ }^{13} \mathrm{C}$ which becomes incorporated in depositing calcite. Since the degassing of fluid did occur at Yucca Mountain, this mechanism could be relevant; however, taking into account that the degassing was likely brief, the significance of this process is uncertain.

Another way of depositing the ${ }^{13} \mathrm{C}$-enriched calcite is to involve the $\mathrm{CO}_{2}$ enriched in ${ }^{13} \mathrm{C}$ isotope in the depositional process. It is thought that $\mathrm{CO}_{2}$ liberated by thermal decarbonation of carbonate rocks during contact metamorphism is about $6 \%$ richer in ${ }^{13} \mathrm{C}$ than the original carbonate (Shieh \& Tailor, 1969; Turi, 1986). Theoretically, if the Palaeozoic carbonate rocks underlying the Yucca Mountain rhyolites underwent decarbonation upon contact with a magmatic intrusion at depth, calcite formed with involvement of the evolved $\mathrm{CO}_{2}$ could be tagged by "heavy positive" $\delta^{13} \mathrm{C}$ values. Recent studies, however, indicate that $\mathrm{C}$ isotope fractionation associated with thermal decarbonation might be much smaller than previously thought. Shapr et al. (2003) reported that in their decarbonation experiments carried out at 3 bar He pressure, $\delta^{13} \mathrm{C}$ values of evolved $\mathrm{CO}_{2}$ were almost identical to those of the original calcite and dolomite. (Previous experiments, in which a $6 \%$-enrichment was observed, were carried under vacuum, which is, arguably, not the best approximation for geological processes). The plausibility of this hypothetical scenario is therefore uncertain.

Methanogenesis. Whelan et al. (2003a) attributed the ${ }^{13} \mathrm{C}$-enrichemnt of the Yucca Mountain calcite to widespread anaerobic conditions and bacterial methanogenesis in the vadose zone. In order to make bacterial methanogenesis possible, however, a number of conditions must be met. Primarily, habitat must be suitable for methanogenic Archaeobacteria, and nutrients and substrates must be available. Most importantly, methanogens, being obligate anaerobes metabolize only in strictly anoxic conditions (Eh < -200 mV; Whiticar et al., 1986). By contrast, waters in the vadose zone of Yucca Mountain have oxidizing character $(\mathrm{Eh}=400-600 \mathrm{mV}$; Fabryka-Martin et al., 2000), controlled by oxygen present in the unsaturated-

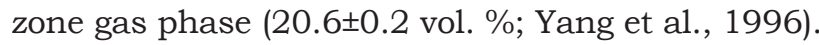

The major redox potential-forming pairs in oxygenated meteoric ground water are $\mathrm{O}_{2} / \mathrm{H}_{2} \mathrm{O}$ and $\mathrm{O}_{2} / \mathrm{H}_{2} \mathrm{O}_{2}$ (Krainov \& Ryzhenko, 1992). When such water moves into deeper parts of the Earth's crust, oxygen spent along the way in various oxidation reactions is not replenished. As a result, the redox potential-forming system of oxygen gradually becomes replaced by other systems (e.g., $\mathrm{Fe}^{2+} / \mathrm{Fe}^{3+}, \mathrm{H}_{2} \mathrm{~S} / \mathrm{SO}_{4}{ }^{2-}$, or $\mathrm{CO}_{2} / \mathrm{CH}_{4}$ ), and the water becomes progressively more reducing. This mechanism does not appear to be relevant in the vadose zone environment of Yucca Mountain, where the subsurface atmosphere is connected with the outside atmosphere and oxygen is readily replenished. In order to create a reducing environment suitable for the development of methanogenic bacteria, not only must the oxygen be somehow expelled from the open fracture network of the Yucca Mountain vadose zone, but in addition its supply must be blocked. There is no apparent and rational explanation for such a scenario.

A separate problem involves nutrients. In a freshwater sulphate-free environment the major substrate for methanogenesis is accumulated organic matter (Whiticar et al., 1986), which is extremely scarce in volcanic tuffs of Yucca Mountain. Infiltrating water is the primary vehicle that could bring organic matter (from soil) into the subsurface. The long-term infiltration rates at Yucca Mountain are thought to range from 2 to $20 \mathrm{~mm} /$ year (DOE, 2001), which means that the water in the vadose zone must have been extremely scarce. Scarcity of water translates into an even greater scarcity of organic matter available as a nutrient for methanogens at Yucca Mountain. Summarizing, the only hypothesis "reconciling" the ${ }^{13} \mathrm{C}$-enrichment of calcite with the "meteoric infiltration" model, hypothesis postulating a widespread reducing environment and bacteriaassisted methanogenesis in the vadose zone of Yucca Mountain (Whelan et al., 2003a), does not seem to be plausible.

Abiogenic isotope fractionation between $\mathrm{CO}_{2}$ and $\mathbf{C H}_{4}$. Of the different carbonate species dissolved in aqueous fluid, only oxidized species participate in precipitation of calcite. Reduced carbon species, such as $\mathrm{CH}_{4}$ (aq) may, through fractionation, affect the isotopic properties of oxidized species and hence, of depositing calcite. Due to the preferential partitioning of "lighter" ${ }^{12} \mathrm{C}$ into $\mathrm{CH}_{4}(a q)$, co-existing oxidized species become enriched in ${ }^{13} \mathrm{C}$, which must be reflected in an increased $\delta^{13} \mathrm{C}$ of calcite, depositing from such solutions. Although it used to be thought that the isotopic exchange between $\mathrm{CO}_{2}$ and $\mathrm{CH}_{4}$ is unlikely to occur below $200^{\circ} \mathrm{C}$ (e.g., Giggenbach, 1982), recent works demonstrated that the exchange is possible at $\leq 200{ }^{\circ} \mathrm{C}$ in the presence of geocatalysts (Horita, 2001).

The oxidation states of carbon species are strongly affected by the fugacity of oxygen (Ohmoto, 1972; Ohmoto and Rye, 1979); the abundance of $\mathrm{CH}_{4}(\mathrm{aq})$ becomes significant at $\log \mathrm{fO}_{2}<-38$ (Faure, 1986). The latter mechanism, therefore, could not have been realized in situ, within the vadose zone of Yucca 
Mountain. This leads to the conclusion that isotope fractionation between $\mathrm{CO}_{2}$ and $\mathrm{CH}_{4}$ responsible for deposition of the ${ }^{13} \mathrm{C}$-enriched calcite occurred at deeper levels of the Earth's crust, where a suitable geochemical environment was present. Mineral forming fluid would have to be introduced into the vadose zone relatively fast, so that it would preserve these "deep-seated" carbon isotope signatures.

\section{Gas chemistry of paleo-fluids}

It is thought that the overall topography of Yucca Mountain remained unchanged, and the 400 to 800 $\mathrm{m}$-thick vadose zone existed at all times over the last 10.6 million years (e.g., DOE, 2001; Whelan et al., 2002). Therefore, the physical processes controlling the migration of gases through the mountain may be expected to persist throughout its history. Since the "meteoric infiltration" model contemplates secondary minerals crystallizing from films of water in the airfilled fractures of the vadose zone (e.g., Paces et al., 2001; Whelan et al., 2002; Wilson et al., 2003), the minerals would be expected to trap in fluid inclusions gases whose chemistry would generally correspond to that of the underground air. According to Sullivan \& Pescatore (1994), Yucca Mountain is a well-ventilated and aerated geological structure, in which gas flow down to a depth of $50-100 \mathrm{~m}$ is influenced by atmospheric pressure, temperature, wind velocity, and topography. Thorstensen et al. (1989) reported that gas samples collected from instrumented boreholes showed concentrations of $\mathrm{O}_{2}$ and $\mathrm{N}_{2}$ that are identical to the atmospheric air values to the limits of analytical precision. Gases from boreholes showed somewhat enriched, relative to outside air, $\mathrm{CO}_{2}$ concentrations of ca. 0.1 vol.\% (Yang et al., 1996) and $\mathrm{CH}_{4}$ concentrations near zero, ranging up to $0.5 \pm 0.1 \mathrm{ppmv}$ (Thorstensen et al., 1989). Soil gases sampled on and near Yucca Mountain had $\mathrm{CH}_{4}$ concentrations that were depleted relative to the atmospheric value of about $1.7 \mathrm{ppmv}$, but still greater than $0.5 \mathrm{ppmv}$ characteristic of the underground air (Thorstensen et al., 1989).

In fluid inclusion studies, compositions of gases are conveniently expressed in the form of gas ratios. If secondary minerals at Yucca Mountain were indeed formed in accord with the "meteoric infiltration" model, the ratios of gases trapped in inclusions would be expected to be similar to those of the underground air. For example, Roedder et al. (1994) interpreted the "atmospheric" $\mathrm{N}_{2} / \mathrm{O}_{2}$ ratios measured in the Yucca Mountain inclusion (Fig. 9-a) as a feature, supporting the "meteoric infiltration" origin of the minerals. It must be noted, however, that this interpretation is equivocal, because hydrothermal

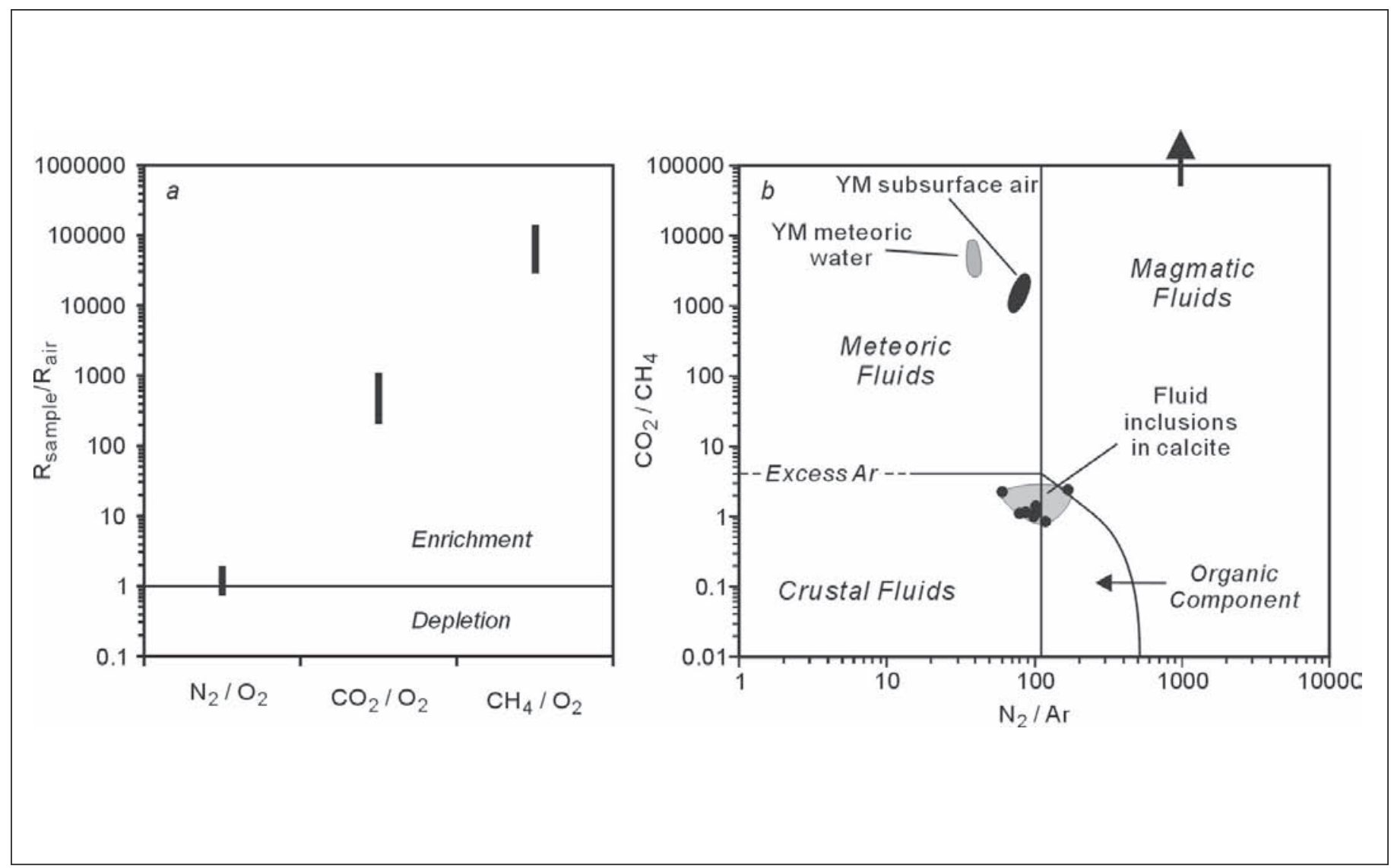

Fig. 9. Analysis of gas data from fluid inclusions from Yucca Mountain calcite (data from Levy et al., 1995). a - Enrichment of fluid inclusion gas ratios $(\mathrm{R})$ relative to the Yucca Mountain underground air. $b$ - Comparison of the fluid inclusion gas data (black dots) with the different types of terrestrial fluids (fields by Norman \& Moore, 1999). Ovals denoted "YM subsurface air" and "YM meteoric waters" correspond to the gas ratios in the Yucca Mountain underground air and waters equilibrated with this air (calculated using HCh code; Shvarov, 1999). Data for underground air are from Yang et al. (1996). 
calcites also have $\mathrm{N}_{2} / \mathrm{O}_{2}$ ratios similar to those of the atmospheric air (Newman et al., 1996). Meanwhile, as it is shown in Fig. 9-a, fluid inclusion gases from Yucca Mountain samples show a strongly elevated, relative to underground air, $\mathrm{CH}_{4} / \mathrm{O}_{2}$ and $\mathrm{CO}_{2} / \mathrm{O}_{2}$ ratios, indicating anoxic reducing conditions during mineral growth. The Yucca Mountain samples show $\mathrm{CO}_{2}-\mathrm{CH}_{4}-\mathrm{N}_{2}-\mathrm{Ar}$ gas compositions consistent with the crustal fluid source and dissimilar, by several orders of magnitude, from the gas chemistry of the modern day waters from the vadose zone of Yucca Mountain (Fig. 9-b).

The presence of large proportions of $\mathrm{CH}_{4}$ and, possibly, higher hydrocarbons (suggested by Raman spectrometry) is important. Hydrocarbon gases are not typically found among fluid inclusion gases in secondary minerals from the magmatic/volcanic rock settings. Meanwhile, as was discussed above, generation of substantial amounts of $\mathrm{CH}_{4}$ in situ, e.g., through bacterial methanogenesis, does not seem to be possible for the vadose zone of Yucca Mountain due to its aerated character and scarcity of nutrients. Hydrocarbons, thus, must have been brought into the vadose zone from elsewhere. The most logical source of these gaseous hydrocarbons is the early Paleozoic carbonate rocks underlying the Yucca Mountain Miocene tuffs. Thermal history of this marine complex indicates that the rocks are over mature from the standpoint of oil generation, but do have thermal potential for gas generation (Grow et al., 1994; French, 2000). On their way to the surface, upwelling waters would pass through the Paleozoic rocks and acquire (dissolve) hydrocarbon gases, which would have been ex-solved into gas phase at shallower levels in the temperature zones of minimum solubility $\left(70\right.$ to $90^{\circ} \mathrm{C}$; Pinneker, 1982).

\section{Isotope properties of paleo-water}

The isotope data obtained from fluid inclusions (see Fig. 6) show a number of rather unusual features. The higher-temperature calcite $\left(\mathrm{T}_{\mathrm{h}}=51-55^{\circ} \mathrm{C}\right)$ contains inclusions that show the "heaviest" $\delta \mathrm{D}$ values and an apparent depletion in ${ }^{18} \mathrm{O}$ so that the data plot to the left of the meteoric water line. Such isotopic properties are unusual for most natural waters, and thus far have only been reported from deep-seated brines and saline groundwaters from crystalline basement rocks (Kloppmann et al., 2002). The $\delta \mathrm{D}$ values decrease with relative time, while $\delta^{18} \mathrm{O}$ do not show any systematic change. We are not aware of any physico-chemical process that would cause natural waters to evolve in such a manner (see, e.g., Clark \& Fritz, 1997); the trend thus more likely reflects mixing of two types of water rather than the evolution of a single water. The low- $\delta \mathrm{D}$ member of the mixture could be organic waters that are generally known to have $\delta \mathrm{D}$ of -90 to $-250 \%$ SMOW (Sheppard \& Charef, 1986). Evidence in support of this hypothesis includes: (a) presence of Paleozoic marine carbonates beneath Yucca Mountain, which are known to have thermal potential for generation of natural gas (Grow et al., 1994; French, 2000); (b) presence of gaseous hydrocarbons in fluid inclusions (see previous section); (c) somewhat elevated $\mathrm{N}_{2}-\mathrm{Ar}$ ratios (see Fig. 9-b) suggesting the involvement of organic matter; and (d) significant positive correlation of the $\delta \mathrm{D}$ values of inclusion waters with the $\delta^{13} \mathrm{C}$ values of the host calcite (Dublyansky \& Smirnov, 2003). Isotopic values of the Yucca Mountain fluid inclusion waters are similar to those of the modern thermal waters of the region, as well as to the values characteristic of the hydrothermal ore deposits in Nevada (Fig. 10).

\section{Paleo-thermometric evidence}

Secondary minerals from Yucca Mountain, were deposited from solutions whose temperatures $\left(65-95^{\circ} \mathrm{C}\right)$ were substantially elevated particularly at early stages of mineral growth, relative to the temperature that would exist under the conditions of "normal" regional heat flow (Dublyansky et al., 2001; Wilson et al., 2003; Whelan et al., 2003b). This is the most important evidence, so that any genetic model must explain the source of energy that heated the mineralforming solutions to unambiguously "hydrothermal" temperatures. Further, the temperatures obtained from fluid inclusions exhibit, within the repository block, a pronounced east-west gradient (see Fig. 5- $d$ ). Thus, not only the elevated temperatures must be explained, but also the non-uniform structure of the paleo-thermal field.

\section{"Conductive heating" thermal model of USGS}

A model that was proposed by the USGS researchers in an attempt to reconcile the paleo-temperature data obtained from fluid inclusions with their "meteoric infiltration" concept calls for a heating of the vadose zone at Yucca Mountain by a magma body emplaced beneath the Timber Mountain caldera, approximately $7-9 \mathrm{~km}$ to the north (Marshall \& Whelan, 2000). According to the thermal model, cooling of the magma body and associated conductive heating of surrounding rocks continued for millions of years, so that meteoric water percolating through this hot rock became heated and deposited secondary minerals. The USGS researchers asserted that thermal simulations carried out by them produced results consistent with the paleo-thermal data obtained from the Yucca Mountain secondary minerals (Marshall \& Whelan, 2001; Whelan et al. 2002; 2004; Marshall et al., 2005). In 2004, the USGS thermal model was evaluated by the U.S. Department of Energy (Behtel SAIC, 2004), and the conclusion was that these simulations have in fact failed to reproduce the empirical data. In addition, observations on the analog system - the 730,000 year-old Long Valley caldera complex in California demonstrated that, consistent with thermal modeling, elevated temperatures do not occur at several-kilometer lateral distance from magma bodies (Behtel SAIC, 2004). We performed thermal simulation of cooling of a magma body using HEAT 3D code (by K. Wohletz, Copyright (C) 1998-2001, The Regents of the University of California) and also were not able to reproduce the temperatures measured in the vadose zone of Yucca Mountain under any geologically reasonable model configurations and boundary conditions.

Temperatures of solutions at early stages of 

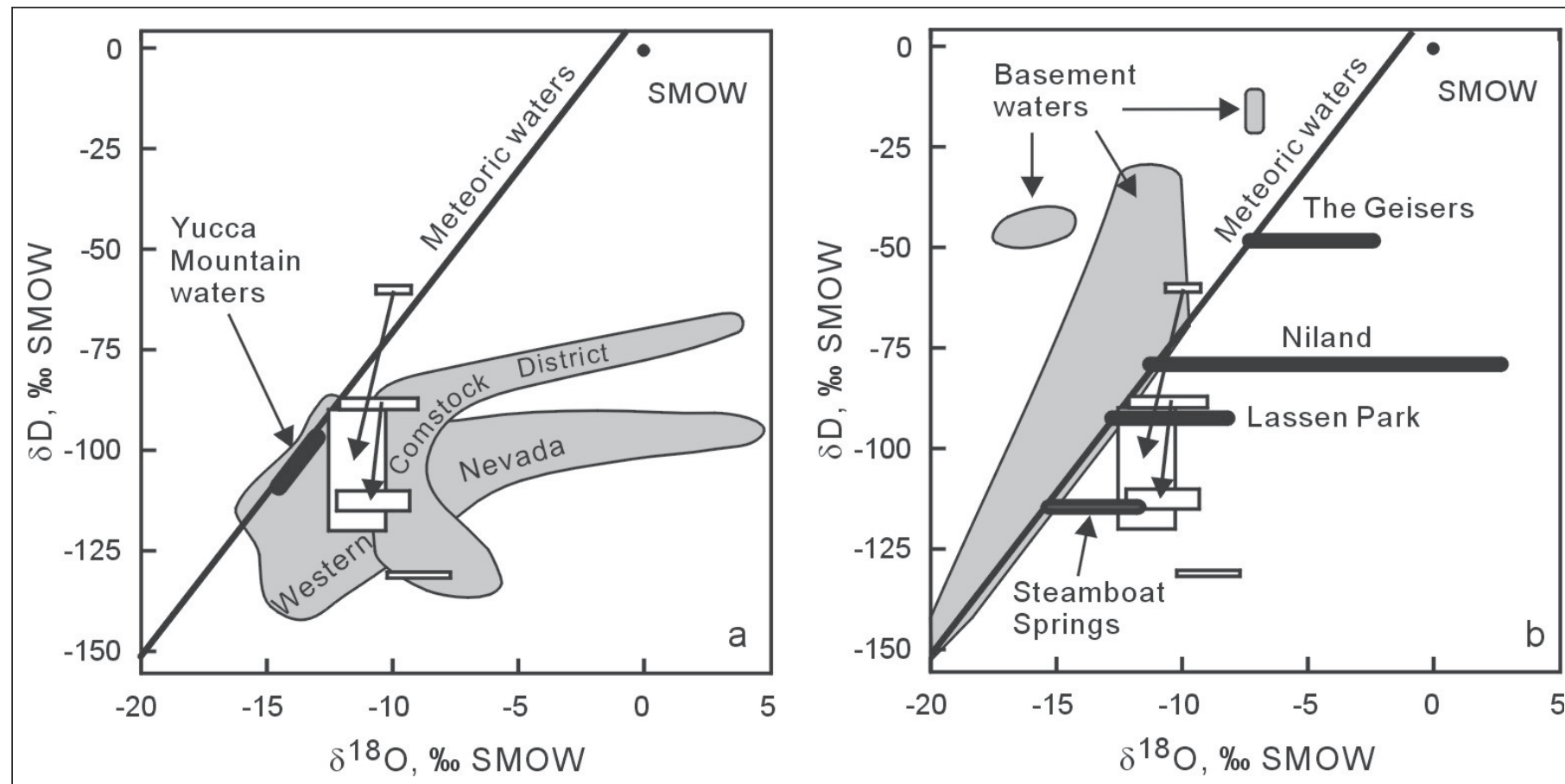

Fig. 10. Comparison of the isotope properties of inclusion waters from the Yucca Mountain calcites (boxes; cf. Fig. 6) with properties of waters that took part in formation of selected hydrothermal ore deposits in Nevada (a) and with modern hydrothermal-meteoric waters of Nevada and California (b). The data: hydrothermal deposits - Criss \& Taylor (1986); modern hydrothermal systems - Hoefs (1986); and basement fluids - Kloppmann et al. (2002). Arrows connecting boxes indicate the trend of isotopic change with time in Yucca Mountain samples.

mineral growth were higher in the eastern part of the repository block, in the vicinity of the Bow RidgePaintbrush fault zone, and lower in the central part of the block (see Fig. 11-a). Nevertheless, largely uniform values of $\delta^{13} \mathrm{C}$ (whose fractionation shows little dependency on the temperature) in early calcite throughout the repository block suggest that different initial temperatures may characterize geochemically (and temporally) identical fluids. The fault zone thus appears to be the "feeder" structure along which the thermal water entered the repository block. The stricture of the paleo-thermal field, shown in Fig. 11$a$ does not appear to have rational explanation within a model envisaging conductive heat transfer from a source located to the north of the ESF-ECRB complex. Meanwhile, this structure is similar to the structure of the modern-day thermal field at the water table (Fig. 11-b), showing maxima associated with fault zones. The latter structure is interpreted as an expression of the convective hydrothermal circulation in the fault zones (Bredehoeft, 1997; Sass, 1999).

\section{ORIGIN OF THE SECONDARY MINERALIZATION AT YUCCA MOUNTAIN}

A picture that emerges from the analysis of the mineralogical and geochemical datais that deep-seated, hot, and equilibrated with reducing environment solutions ascended along the enhanced-permeability zone associated with the deep-seated Paintbrush fault. Being injected into the vadose zone, the fluids moved away from the conduit zone, simultaneously cooling down, degassing, and depositing minerals in the cavities and fractures through which they moved.

A model that explains the physical mechanisms of the injection of deep-seated fluids into the thick vadose zone was proposed by Szymanski \& Harper (2002). It envisages that prior to being injected upward along the fault zone, the fluids accumulated in the hypocentral area of the nucleating earthquake, at a depth of $10-15 \mathrm{~km}$. The hypocentral area is characterized by high temperatures, pressures, and a reducing anoxic environment. The collapse of the dilated hypocentral area during an earthquake expels the accumulated fluids, which gush up, along the most permeable pathway in the fault zone (seismic pumping model of Sibson et al., 1975). Observations of the hydrologic effects of large earthquakes in the Great Basin, e.g., the Hebgen Lake and Borah Peak events, suggest that as much as 0.3 to $0.5 \mathrm{~km}^{3}$ of fluid could be mobilized by seismic pumping (Hickman et al., 1994; Muir-Wood \& King, 1993).

On the way toward Earth's surface, the fluids expelled from the hypocentral area penetrate overlying aquifers. At early stages of this dynamic process, the deep-seated fluids have little interaction with these cooler and more oxidizing waters, so that the first portions of minerals deposited from such fluids would record isotopic properties of more or less unchanged "hypocentral" fluids. At shallow depths, the deepseated fluids are expected to experience extensive degassing in response to decreasing pressure and temperature. This leads to heterogenization of the fluid into liquid and gaseous phases (recorded by the co-existing gas- and liquid-dominated inclusions in 


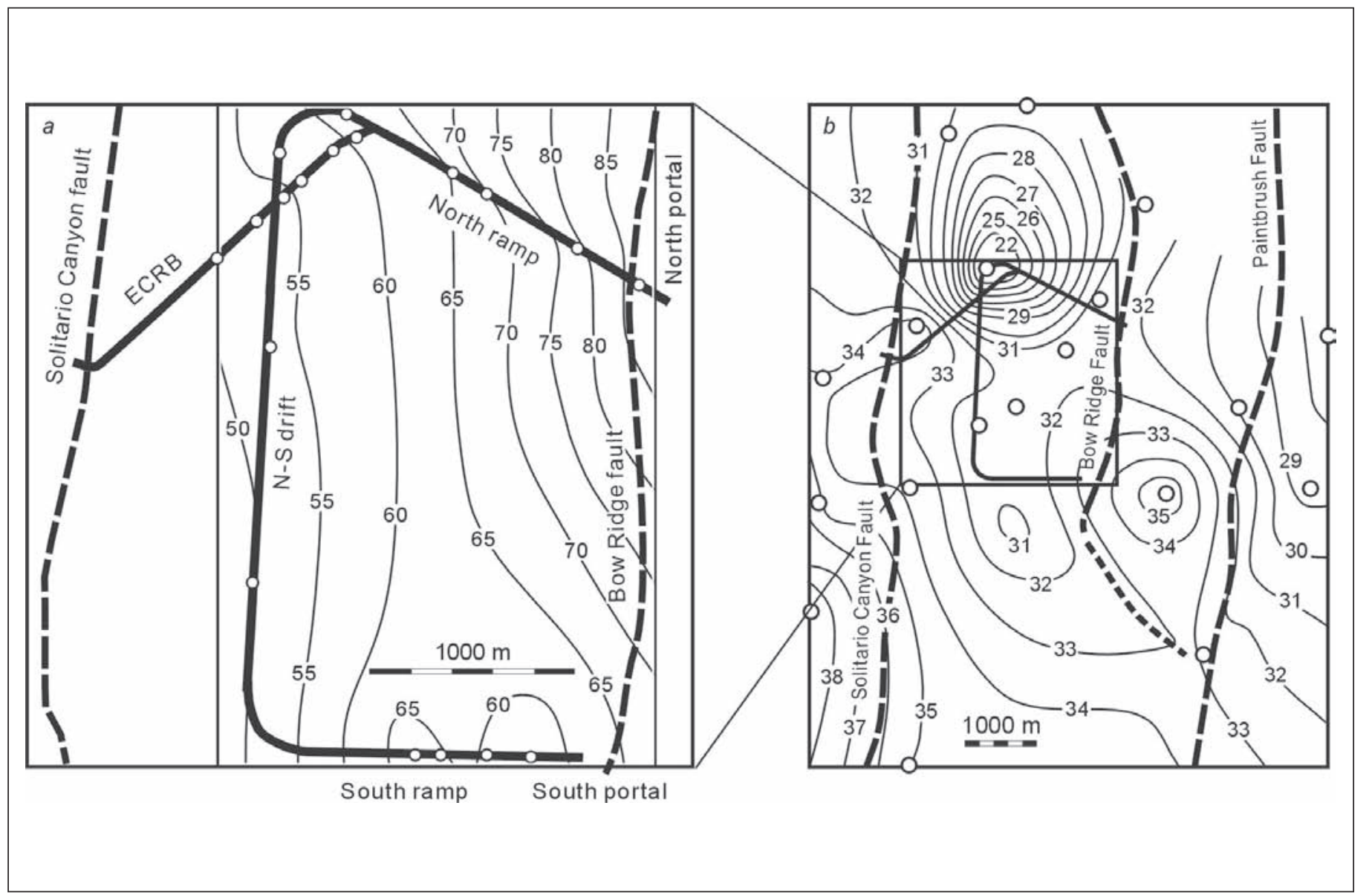

Fig. 11. Paleo- and modern temperature fields at Yucca Mountain. a - Reconstructed field of maximum modal paleo-temperatures ( $\left.{ }^{\circ} \mathrm{C}\right)$ in the repository block, at the ESF level, by fluid inclusions. Circles indicate locations of samples; b - Present-day temperatures measured in boreholes (circles) at the water table $\left({ }^{\circ} \mathrm{C}\right)$. Note two maxima interpreted as indication of hydrothermal circulation along the horst-bounding fault zones (Sass et al., 1987). The map a is constructed on the basis of the data reported in Dublyansky et al. (2001); Wilson et al. (2003); and Whelan et al. (2003b). The map $b$ is plotted on the basis of the data from Sass et al. (1987).

secondary minerals). An additional factor leading to "local" heterogenization is the changing geometry of individual fluid conduits (the drop of pressure when fluid enters form a thin fracture into a cavity).

As a result of the initial injection of the deep-seated fluids into the vadose zone, the relatively thin zone of enhanced permeability associated with fault becomes filled with heated fluids. This configuration is buoyantly unstable, which leads to the development of the socalled Rayleigh-Bénard instabilities or convection cells (Murphy, 1979). At this stage, the involvement of the aquifer fluids in circulation is expected. In depositing minerals, this stage would be expressed through decreasing fluid inclusion temperatures and evolving isotopic properties from those of "hypocentral" fluids to "aquifer" fluids.

Fluids injected in the vadose zone form a "hydraulic mound" centered at the most permeable section of the fault. The mound, in which the water might be elevated by several hundred meters relative to the "stable" water table, would necessarily be a transient hydrological feature. The dissipation of the mound takes the form of a lateral (away from the fault) and downward (toward the water table) flow, a pattern, which is modulated by the permeability structure of the rock.

\section{CONCLUSIONS}

Our overall conclusion is that the "meteoric infiltration" or "speleothemic" model for deposition of secondary minerals at Yucca Mountain (Paces et al., 2001; Whelan et al., 2002, Wilson et al., 2003) is not supported by factual evidence. In such interpretation, the mineral deposits must be corallites and crystallictites, branching aggregates formed from capillary thin films. These speleothems have distinctive morphologies and aggregate textures (as defined by Stepanov, 1997), which are not observed in the Yucca Mountain samples. Geochemical evidence (strong ${ }^{13} \mathrm{C}$-enrichemnt of calcite, gas composition of fluid inclusions, isotope composition of fluid inclusion water) also does not seem to be compatible with the postulated "speleothemic" model. Consequently, the attempts to use the Yucca Mountain minerals to reconstruct such paleo-hydrogeological parameters as past seepage volumes or infiltration fluxes (e.g., Marshall et al., 2003; Xu et al, 2003), or get insight into the Quaternary paleo-climate (e.g. Wilson et al., 2003) appear to be futile.

\section{ACKNOWLEDGMENTS}

Most of the field and laboratory research discussed in this paper was funded by the State of Nevada 
through Agency for Nuclear Projects - Nuclear Waste Project Office (Carson City, NV, U.S.A.). Office of the Attorney General, State of Nevada and Institute for Energy and Environmental Research (Washington, DC) both have played crucial role in initiation, in 1998, of the independent research on the Yucca Mountain secondary minerals. Dr. R. Bodnar has kindly provided facilities and equipment for fluid inclusion studies at Virginia Tech (Blacksburg, VA). Drs. Z. Sharp, J. Selverstone, and V. Atudorei of the University of New Mexico (Albuquerque, NM) have helped with coupled stable isotope - fluid inclusion studies. The authors are thankful to J.Szymanski, S.Pashenko, G.Palyanova, O.Gaskova, and H.Swainston for many stimulating discussions.

\section{REFERENCES}

Aliev R., 1966 -Ontogenetic studies of calcite crystals from Dashkesan iron-ore deposit. In: Grigoriev D.P. (Ed) -Origin of mineral individuals and aggregates. Nauka, Moscow:181-200. In Russian

Aquilano D., Costa E., Genovese A., Massaro F.R., and Rubbo M., 2003 -Heterogenous nucleation and growth of crystalline micro-bubbles around gas cavities formed in solution. Progr. Cryst. Growth and Characterizat. of Mater., 46:59-84.

Bechtel SAIC, 2004 -Technical Basis Document No. 2: Unsaturated Zone Flow. Appendix H: Analog and geochemical evidence for Yucca Mountain thermalhydrothermal history. Prepared by Bechtel SAIC Company, LLC for U.S. Department of Energy Office of Civilian Radioactive Waste Management, Office of Repository Development:H-1-H-30.

Benson, L. \& Klieforth, H., 1989 -Stable Isotopes in Precipitation and Groundwater in the Yucca Mountain Region, Southern Nevada: Paleoclimatic Implications. Amer. Geophys. Union Geophys. Monograph 55:41-59.

Bish D.L. \& Aronson J.L., 1993 -Paleogeothermal and Paleohydrologic Conditions in Silicic Tuff from Yucca Mountain, Nevada. Clays and Clay Minerals, 41(2):148-161.

Bredehoeft J.D., 1997 -Fault permeability near Yucca Mountain. Wat. Resours. Res., 33(11):2459-2463.

Budai J.M., Martini A.M., Walter L.M., \& Ku T.C.W., 2002 -Fracture-fill calcite as a record of microbial methanogenesis and fluid migration: a case study from the Devonian Antrim Shale, Michigan Basin. Geofluids 2:163-183.

Burke E., 2001 -Raman microspectrometry of fluid inclusions. Lithos, 55:139-158.

Carlos B.A., Chipera S.J., Bish D.L., \& Craven S.J., 1993 -Fracture-Lining Manganese Oxide Minerals in Silicic Tuff, Yucca Mountain, Nevada, USA. Chem. Geol., 107(1-2):47-69.

Chernov A.A., Givargizov E.I., Bagdasarov K.S., Kuznetsov V.A., Demyanets L.N., \& Lobachev A.N., 1980 -Modern crystallography. Nauka, Moscow. In Russian

Clark I.D. \& Fritz P., 1997 -Environmental Isotopes in Hydrogeology. Lewis Publishers, Boca Raton, FL.

Criss R.E. \& Taylor H.P. (Jr.), 1986 -Meteorichydrothermal systems. In: Valley, J., Taylor, H., O'Neil, J. (Eds.) -Stable Isotopes in High-Temperature Geological Processes. Reviews in Mineralogy. Min. Soc.
Am. v. 16:373-424.

Davis S.N. \& DeWiest J.M., 1966 -Hydrogeology. John Wiley and Sons, New York-London-Sydney.

Day W.C., Dickerson R.P., Potter C.J., Sweetkind D.S., San Juan C.A., Drake R.M., \& Fridrich C.J., 1998 Bedrock geologic map of the Yucca Mountain area, Nye County, Nevada. U.S. Geol. Surv. Geol. Investigations Series.

DOE (U.S. Department of Energy) 1993 -Report on the Origin of Calcite-Silica Deposits at Trench 14 and Busted Butte and Methodologies Used to Determine Their Origin. Report YMP193-11-R. 64 p.

DOE (U.S. Department of Energy) 1998 -Viability Assessment of a Repository at Yucca Mountain. Vol. 1. Introduction and Site Characterization. DOE/RW-0508.

DOE (U.S. Department of Energy) 2001 -Yucca Mountain Science and Engineering Report. Technical Information Supporting Site Recommendation Consideration. U.S. Department of Energy. DOE/RW-0539.

Dublyansky Y.V., 1995 -Speleogenetic History of the Hungarian Hydrothermal Karst. Environ. Geol. 25(1):24-35.

Dublyansky Y.V., 2001 -Environment of deposition suggested by all-gas inclusions and stable isotopes in secondary minerals from Yucca Mountain, Nevada, USA. In: Noronha F. \& Guedes A. (Eds) -XVI ECROFI Conference. Faculdade de Ciencias do Porto, Departamento de Geologia:131-134.

Dublyansky Y.V. \& Pashenko S.E., 1997 -Cave popcorn an aerosol speleothem? Proc. 12th Int. Congr. Speleol., Switzerland. 1:271-274.

Dublyansky Y.V. \& Smirnov S.Z., 2003 -Review of the report "Thermochronological evolution of calcite formation at the potential Yucca Mountain repository site, Nevada". Publishing House SB RAS, Novosibirsk. 43 p.

Dublyansky Y., Ford D., \& Reutski V., 2001. -Traces of epigenetic hydrothermal activity at Yucca Mountain, Nevada: preliminary data on the fluid inclusion and stable isotope evidence. Chem. Geol. 173:125-149.

Dublyansky Y.V., Smirnov S.Z., Pashenko S.E., 2003 -Identification of the deep-seated component in paleo fluids circulated through a potential nuclear waste disposal site: Yucca Mountain, Nevada, USA. J. Geochem. Explor., 78-79:39-43.

Etoh J., Izawa E., Watanabe K., Taguchi S., \& Sekine R. 2002 -Bladed quartz and its relationship to gold mineralization in the Hishikarilow-sulfidation epithermal gold deposit, Japan. Econom. Geol., 97: 1841-1851.

Fabryka-Martin J., Meijer A., Marshall B., Neymark L., Paces J., Whelan J., \& Yang A., 2000 -Analysis of Geochemical Data from the Unsaturated Zone. ANLNBS-HS-000017, Rev. 00. 156 p.

Faure G., 1986 -Principles of Isotope Geology. John Wiley $\&$ Sons, New York.

French D.E., 2000 -Hydrocarbon assessment of the Yucca Mountain vicinity, Nye County, Nevada. Open-File Rep. 2000-2. Nevada Bureau of Mines and Geology, Reno, NV, USA.

Frisia S., Borsato A., Fairchild I.J., \& McDermott F. 2000 -Calcite fabrics, growth mechanisms, and environments of formation in speleothems from the Italian Alps and southwestern Ireland. J. Sed. Res., 70(5):1183-1196. 
Giggenbach W.F., 1982 -Carbon-13 exchange between $\mathrm{CO}_{2}$ and $\mathrm{CH}_{4}$ under geothermal conditions. Geochim. Cosmochim. Acta, 46:159-165.

Goldstein R. \& Reynolds J., 1994 -Systematics of fluid inclusions in diagenetic minerals. SEPM Short Course No.31.

Gonfiantini R., Panici C., \& Tongiorgi, E. 1968 -Isotopic Disequilibrium in Travertine Deposition. Earth Planet. Sci. Let. 5:55-58.

Grigoriev D.P. \& Zhabin A.G., 1975-Ontogeny of minerals. Individuals. Nauka, Moscow. 200 p. In Russian

Grow J., Barker C., \& Harris H., 1994 -Oil and gas exploration near Yucca Mountain, Southern Nevada. Proc. Int. Con., Amer. Nucl. Soc. "High-Level Radioactive Waste Management”. La Grande Park, Illinois:1298-1315.

Hickman S., Sibson S., \& Brune R., 1994 -Proceedings of Workshop LXIII, the Mechanical Involvement of Fluids in Faulting. U.S. Geol. Survey Open-File Report 94-228.

Hill C. \& Forti P., 1997 -Cave minerals of the World. National Speleological Society, Huntsville, AL, U.S.A.

Hoefs J., 1986 -Stable Isotope Geochemistry. SpringerVerlag, Berlin, Heidelberg, New York, London, Paris, Tokyo.

Horita J., 2001 -Carbon isotope exchange in the system $\mathrm{CO}_{2}-\mathrm{CH}_{4}$ at elevated temperatures. Geochim. Cosmochim. Acta, 65:1907-1919.

Ikornikova N., 1975 -Hydrothermal crystal synthesis in chloride systems. Nauka, Moscow. In Russian

Kalb G., 1929 -Bemerkungen zu den minerogenetischen Kristalltrachtstypen des Kalkspates. Zbl. Mineral., Abt. A,4:137-138.

Kendall A.C. \& Broughton P.L., 1978 -Origin of fabric in speleothems composed of columnar calcite crystals. Jour. Sed. Petrol., 48(2):519-538.

Kim S.-T. \& O'Neil J.R., 1997 -Equilibrium and nonequilibrium oxygen isotope effects in synthetic carbonates. Geochim. Cosmochim. Acta, 61:3461-3475.

Kloppmann W., Girard J.-P., \& Négrel P., 2002 -Exotic stable isotope compositions of saline waters and brines from the crystalline basement. Chem. Geol., 184:49-70.

Krainov S.R. \& Rizhenko B.N., 1992 -Redox potentialforming systems of groundwaters: Thermodynamic and kinetic aspects. Geokhimia, 4:467-482. In Russian.

Krasnova N.I. \&

Petrov T.G., 1997 -Genesis of mineral individuals and aggregates. Nevsky kuryer, St.-Petersburg. In Russian.

Levy S., Chipera S., \& Norman D., 1995 -Alteration History Studies in the Exploratory Studies Facility, Yucca Mountain, Nevada, USA. Proc. Materials Res. Soc. Symposium "Scientific Basis for Nuclear Waste Management XIX", Nov. 27-Dec.1, 1995, Boston, MA, USA:783-790.

Marshall B. \& Whelan J., 2000 -Isotope geochemistry of calcite coatings and the thermal history of the unsaturated zone at Yucca Mountain, Nevada. Geol. Soc. Amer. Abstracts with Program. 32(7):A-259.

Marshall B.D. \& Whelan J.F., 2001 -Simulating the Thermal History of the Unsaturated Zone at Yucca Mountain, Nevada. Geol. Soc. Amer. Abstracts with Program. 33(6):A-375.

Marshall B.D., Neymark L.A., \& Peterman Z.E., 2003
- Estimation of past seepage volumes from calcite distribution in the Topopah Spring Tuff, Yucca Mountain, Nevada. J. Contam. Hydrol., 62-63:237-247.

Marshall B.D., Neymark L.A., \& Peterman Z.E., 2005 -Reply to "Commentary: Assessment of past infiltration fluxes through Yucca Mountain on the basis of the secondary mineral record-is it a viable methodology?" By Y.V. Dublyansky and S.Z. Smirnov. J. Contam. Hydrol., 77:219-224.

McConnaughey T.A., Whelan J.F., Wickland K.P., \& Moscati R.J., 1994 -Isotopic Studies of Yucca Mountain Soil Fluids and Carbonate Pedogenesis. Proc. Int. Con., Amer. Nucl. Soc. "High-Level Radioactive Waste Management”. La Grande Park, Illinois:2584-2589.

Meijer A. \& Kwicklis E., 2000 -Geochemical and Isotopic Constraints on the Groundwater Flow Directions, Mixing, and Recharge at Yucca Mountain, Nevada. U.S. DOE, Office of Civil Radioactive Waste Management, Analysis Model Report ANL-NBS-HS-000021. 131 p.

Moore G.W. \& Sullivan G.N., 1964 -Speleology, the study of caves. Boston, D.C. Heath and Co.

Moore J.N., Norman D.I., \& Kennedy B.M., 2001 -Fluid inclusion gas compositions from an active magmatic hydrothermal system: a case study of the compositions from an active magmatic-hydrothermal system: a case study of the Geysers geothermal field, USA. Chem. Geol., 173:3-30.

Muir-Wood R. \& King G.C.P., 1993 -Hydrological Signatures of Earthquake Strain. J. Geophys. Res., 98(B12):22035-22068.

Murphy H.D., 1979 -Convective Instabilities in Vertical Fractures and Faults. J. Geoph. Res., 84.

Newman B.D., Norman D.I., Gundimeda N., \& Levy S.S., 1996 -Understanding the genesis of nonmarine calcite deposits through quadrupole mass spectrometric analysis of fluid inclusion gases. Chem. Geol., 132:205-213.

Neymark A.L. Amelin Y.V., \& Paces J.B., $2000-{ }^{206} \mathrm{~Pb}^{230} \mathrm{Th}-$ ${ }^{234} U{ }^{238} \mathrm{U}$ and ${ }^{207} \mathrm{~Pb}^{235} \mathrm{U}$ geochronology of Quaternary opal, Yucca Mountain, Nevada. Geochim. Cosmochim. Acta, 64(17):2913-2928.

Neymark L.A., Amelin Y., Paces J.B., \& Peterman Z.E., $2002-U-P b$ ages of secondary silica at Yucca Mountain, Nevada: Implications for the paleohydrology of the unsaturated zone. Appl. Geochem. 17:709-734.

Norman D.I. \& Moore J.N., 1999 -Methane and excess $\mathrm{N}_{2}$ and $\mathrm{Ar}$ in geothermal fluid inclusions. Proc. $24^{\text {th }}$ Workshop Geotherm. Reservoir Eng., Stanford Univ.:196-202.

Ohmoto H., 1972 -Systematics of sulfur and carbon isotopes in hydrothermal ore deposits. Econ. Geol. 67:551-578.

Ohmoto H. \& Rye R.O., 1979-Isotopes of sulfur and carbon In: Barnes H.L. (Ed) -Geochemistry of Hydrothermal Ore Deposits. John Wiley, New York:509-567.

Onac B.P., 1997 -Crystallography of Speleothems In: Hill C. \& Forti P. (Eds) -Cave minerals of the World. National Speleological Society, Huntsville, AL, U.S.A.:230-236.

Paces J.B., Neymark L.A., Marshall B.D., Whelan J.F., \& Peterman Z.E., 2001 -Ages and Origins of Calcite and Opal in the Exploratory Studies Facility Tunnel, Yucca Mountain, Nevada. U.S. Geol. Surv. Water-Resour. Invest. Rep. 01-4049. 
Peterman Z.E., Stuckless J.S., Marshall B.D., Mahan S.A., \& Futa K., 1992 -Strontium isotope geochemistry of calcite fracture fillings in deep core, Yucca Mountain, Nevada-A progress report. Proc. Int. Con., Amer. Nucl. Soc. "High-Level Radioactive Waste Management". La Grande Park, Illinois:1582-1586.

Pinneker E.V. (Ed.), 1982 -Principles of Hydrogeology. Geological activity and history of water in the Earth's interiors. Nauka, Novosibirsk. In Russian.

Quade J. \& Cerling T.E., 1990 -Stable isotopic evidence for a pedogenic origin of carbonates in trench 14 near Yucca Mountain, Nevada. Science, 250:1549-1552.

Roedder E., Whelan J.F., \& Vaniman D.T., 1994 -Fluid Inclusion Studies of Calcite Veins from Yucca Mountain, Nevada, Tiffs: Environment of Formation. Proc. Int. Con., Amer. Nucl. Soc. "High-Level Radioactive Waste Management”. La Grande Park, Illinois:1854-1860.

Rye R.O. \& Ohmoto H., 1974 -Sulfur and Carbon Isotopes and Ore Genesis: A Review. Econ. Geol., 69:826-842.

Sass J., 1999 -Thermal Manifestation of Hydrologic Phenomena in the Great Basin of the Southwestern United States. Suppl. to EOS, April 27, 1999.

Sass J.H., Lachenbruch A.H., Dudley W.W., Priest S.S., \& Munroe R.J., 1987 -Temperature, Thermal Conductivity, and Heat Flow near Yucca Mountain, Nevada: Some Tectonic and Hydrologic Implications. U.S. Geol. Surv. Open-File Report 87-649. 118 p.

Self C.A. \& Hill C.A., 2003 -How speleothems grow: An introduction to the ontogeny of cave minerals. J. Cave and Karst Studies 65(2):130-151.

Serban M., Viehman I., \& Coman D., 1961 -Caves of Romania. Meridiane, Bucharest.

Sharp Z.D., 1992 -In situ laser microprobe techniques for stable isotope analysis. Chem. Geol., 101:3-19.

Sharp Z.D. \& Cerling T.E., 1996 -A laser GC-IRMS technique for in situ stable isotopic analyses of carbonates and phosphates. Geochim. Cosmochim. Acta., 60(15):2909-2916.

Sharp Z.D., Papike J.J., \& Durakiewicz T., 2003 -The effect of thermal decarbonation on stable isotope compositions of carbonates. Am. Mineral., 88:87-92.

Sheppard S.M.F. \& Charef A., 1986 -Eau organique: characterisaion isotopique et evidence de son role dans la gisement $\mathrm{Pb}-\mathrm{Zn}$ de Fedj-el-Adoum, Tunissie. C. R. Acad. Sci. Ser. II, 302:1189-1192.

Shieh Y.N. \& Taylor H.P. (Jr.), 1969 -Oxygen and carbon isotope studies of contact metamorphism of carbonate rocks. J. Petrol., 10:307-331.

Shvarov Y.V., 1999 -Algorithmization of the Numeric Equilibrium Modeling of Dynamic GeochemicalProcesses. Geochem. Int., 6:571-576.

Sibson R.H., Moore J.M., \& Rankin A.H., 1975 -Seismic Pumping - a Hydrothermal Fluid Transport Mechanism. J. Geol. Soc. of London, 131.

Smirnov S. \& Dublyansky Y., 2001 -Ontogenetic Mineralogy of Secondary Minerals at Yucca Mountain, Nevada. Proc. Int. Con., Amer. Nucl. Soc. "High-Level Radioactive Waste Management". La Grande Park, Illinois. CD ROM.

Stepanov V.I., 1997 -Notes on mineral growth from the archive of V.I.Stepanov (1924-1988). Proc. of the Univ. of Bristol Spelaeological Soc., 21(1):25-42.
Stuckless J.S., Peterman Z.E., \& Muchs D.R. $1991-U$ and $\mathrm{Sr}$ isotopes in Ground Water and Calcite, Yucca Mountain, Nevada: Evidence Against Upwelling Water. Science, 254:551-554.

Sullivan T.M. \& Pescatore C., 1994 -Release of Radon Contaminants from Yucca Mountain: The Role of Buoyancy Driven Flow. Report to the U.S. DOE on contract DE-AC02-79CH00016. Brookhaven National Laboratory, Environmental and Waste Technology Center.

Sunagawa I., 1953 -Variation of crystal habit of calcite, with special reference to the relation between crystal habit and crystallization stage. Rep. Geol. Survey Japan. No. 155.

Sunagawa I., 1982 -Morphology of crystals in relation to growth conditions. Estudios geol. 38:127-134.

Szabo B.J. \& Kyser T.K., 1990 -Ages and stable-isotope compositions of secondary calcite and opal in drill cores from tertiary volcanic rocks of the Yucca Mountain, Nevada. Geol. Soc. Amer. Bull. 102:1714-1719.

Szymanski J.S. \& Harper T.R., 2002 -Suitability of the Yucca Mountain Site to Accommodate a Permanent Repository for High-Level Radioactive Waste and Spent Nuclear Fuel: an Independent Assessment. Part One, Synthesis: Contemporary State and Evolution of the Geologic System at Yucca Mountain. Report to the Office of the Attorney General, State of Nevada.

Talma A.S. \& Netterberg F., 1983 -Stable isotope abundances in calcretes. In: Wilson R.C.L. (Ed.) Residual deposits: Surface Related Weathering Processes and Materials. Geol. Soc. London:221-233.

Thorstensen D.C., Weeks E.P., Haas H., \& Woodward J.C. 1989 -Physical and Chemical Characteristics of Topographically Affected Airflow in an Open Borehole at Yucca Mountain, Nevada. Proc. of the Conf. "Nuclear Waste in the Unsaturated Zone", September 18-21, Las Vegas, Nevada.

Turi B., 1986 -Stable Isotope Geochemistry of Travertines. In: Fritz, P., Fontes, J.Ch. (Eds.) Handbook of Environmental Isotope Geochemistry. 2. The terrestrial Environment, B. Elsevier, Amsterdam:207-238.

Vaniman D.T., 1993 -Calcite deposits in fractures at Yucca Mountain, Nevada. Proc. Int. Con., Amer. Nucl. Soc. "High-Level Radioactive Waste Management". La Grande Park, Illinois:1935-1939.

Whelan J.F. \& Stuckless J.S., 1991 -Paleohydrologic Implications of the Stable Isotope Composition of Secondary Calcite within the Tertiary Volcanic Rocks of Yucca Mountain, Nevada. Proc. Int. Con., Amer. Nucl. Soc. "High-Level Radioactive Waste Management". La Grande Park, Illinois:1572-1581.

Whelan J.F., Vaniman D.T., Stuckless J.S., \& Moscati R.J., 1994 -Paleoclimatic and Paleohydrologic Records from Secondary Calcite: Yucca Mountain, Nevada. Proc. Int. Con., Amer. Nucl. Soc. "High-Level Radioactive Waste Management”. La Grande Park, Illinois:2738-2745.

Whelan J.F., Paces J.B., \& Peterman Z.E., 2002 -Physical and stable-isotope evidence for formation of secondary calcite and silica in the unsaturated zone, Yucca Mountain, Nevada. Appl. Geochem., 17:735-750.

Whelan J., Neymark L.A., \& Moscati R.J., 2003a-Evidence from secondary calcite $\delta^{13} \mathrm{C}$ values of unsaturated- 
zone depositional conditions and past climate at Yucca Mountain, Nevada. GSA Abstr. with Progr. Seattle, WA, USA.

Whelan J.F., Roedder E., Neymark L.A., \& Moscati R.J., 2003b -Thermochronology of Secondary Minerals from the Yucca Mountain Unsaturated Zone. Proc. Int. Con., Amer. Nucl. Soc. "High-Level Radioactive Waste Management". La Grande Park, Illinois, CD ROM

Whelan J.F., Paces J.B., Peterman Z.E., Marshall B.D., \& Neymark L.A., 2004 -Reply to the comment on "Physical and stable-isotope evidence for formation of secondary calcite and silica in the unsaturated zone, Yucca Mountain, Nevada", by Y.V. Dublyansky, S.E. Smirnov and G.P. Palyanova. Appl. Geochem., 19:1879-1889.

Whiticar M.J., Faber E., \& Schoell M., 1986 -Biogenic methane formation in marine and freshwater environments: $\mathrm{CO}_{2}$ reduction $v$ s acetate fermentation - isotope evidence. Geochim. Cosmochim. Acta, 50:693-709.

Wilson N.S.F., Cline J.S., \& Amelin Y.V., 2003 -Origin,
Timing, and Temperature of Secondary Calcite-Silica Mineral Formation at Yucca Mountain, Nevada. Geochim. Cosmochim. Acta, 67 (6):1145-1176.

Xu T., Sonnenthal E., \& Bodvarsson G., 2003 -A reactiontransport model for calcite precipitation and evaluation of infiltration fluxes in unsaturated fractured rock. J. Contam. Hydrol. 64:113-127.

Yang I.C., Rattray G.W., \& Yu P., 1996 -Interpretation of chemical and isotopic data from boreholes in the unsaturated zone at Yucca Mountain, Nevada. U.S. Geol. Surv. Water-Res. Invest. Rep. 96-4058.

Yushkin N.P., 1966 -Morphology and growth of splintered celestite crystals (on the example of Shor-Sou Deposit, Uzbekistan). In: Grigoriev D.P. (Ed) -Origin of mineral individuals and aggregates. Nauka, Moscow:201-215. In Russian.

Zielinski R.A., 1982 -Uraniferous opal, Virgin Valley, Nevada: Conditions of Formation and Implications for Uranium Exploration. Journ. Geochem. Explor. 16:197-216. 